\title{
PROBLEM CHRONOLOGII ZOLNIKA Z GRODZISKA W CHOTYŃCU I TWORZĄCYCH GO POZIOMÓW UŻYTKOWYCH W ŚWIETLE BADAŃ NAD KLASYFIKACJĄ I DATOWANIEM SZPIL*
}

\author{
THE PROBLEM OF THE CHRONOLOGY OF THE ZOLNIK FROM \\ THE BURGWALL IN CHOTYNIEC, POLAND AND ITS USAGE LEVELS \\ IN LIGHT OF RESEARCH ON THE CLASSIFICATION AND DATING OF PINS
}

The article presents the partial results of archaeological research carried out on the burgwall zolnik in Chotyniec, site 1. It aims to classify the historical objects discovered in terms of functional qualification - namely, the pins that were found in 2017-2019, and to introduce them into the scientific circulation. This interesting and relatively numerous series of artifacts complements and enriches our knowledge on many aspects of the zolnik's function, including its chronology and cultural connections. In this sketch, an analysis of the typological and chronological position of the pins was carried out, and on its basis an attempt was made to estimate the dating of the zolnik (the usable levels that form it).

KEY WORDS: early Iron Age, pins, Scythian cultural circle, zolnik, south-eastern Poland

Pomimo wzmianek w piśmiennictwie archeologicznym (Kunysz 1968, 46) oraz utrwalenia w źródłach kartograficznych (Czopek 2019, ryc. 3) grodzisko w Chotyńcu stosunkowo późno doczekało się zainteresowania ze strony archeologów. Prace wykopaliskowe na tym terenie prowadzone są dopiero od 2016 roku (Czopek et al. 2017, 297n). Zapoczątkowano je jeszcze $\mathrm{w}$ ramach programu badawczego pt. Przemiany kulturowo-osadnicze w do-

* Publikacja jest wynikiem realizacji projektu (grantu) Narodowego Centrum Nauki nr 2017/27/B/HS3/01460 pt. Na granicy dwóch światów. Aglomeracja chotyniecka scytyjskiego kregu kulturowego - etap 1: badania terenowe. rzeczu rzeki Wiszni w epoce brazu $i$ we wczesnej epoce żelaza $w$ kontekście zmian prahistorycznej i wczesnośredniowiecznej ekumeny, a obecnie badania te wspiera finansowo grant Narodowego Centrum Nauki nr 2017/27/B/HS3/01460. Jedynym jak do tej pory miejscem na majdanie, które przebadane zostało w sposób kompleksowy i całkowity, jest tzw. zolnik. Kontekstem kulturowym dla tego odkrycia są założenia interpretowane jako miejsca powtarzalnych praktyk rytualno-obrzędowych (Gretchko 2010, 29), znane ze strefy leśnostepowej Europy wschodniej, tj. z obszaru wchodzącego w skład „Wielkiej Scytii” (Czopek 2019). Informacje, jakie zgromadzono podczas trzech sezonów badań archeologicznych (2017-2019) na tym wyjątkowym obiekcie, znacząco wzbogacają 
naszą wiedzę na temat kultury materialnej i duchowej ugrupowań zamieszkujących grodzisko.

Obiekt, o którym mowa, manifestował swoją obecność na powierzchni stanowiska jako wyraźne zaciemnienie warstwy ornej oraz miejsce dużego zagęszczenia treści kulturowej (ceramika, kości i polepa). Miał on kształt zbliżony do okręgu o średnicy ok. $21 \mathrm{~m}$. Na podstawie złożonej stratygrafii oraz liczby pozyskanych z niego artefaktów można stwierdzić, że było to założeniem długotrwale i intensywnie użytkowane. Na wcześniej wyrównanym terenie usytuowano podstawę kompleksu, która miała postać lekko stożkowatego nasypu z żółtej gliny. Kolejno w strukturze zolnika znajdowały się następujące komponenty: 1) intensywnie czarna warstwa spalenizny, tzw. „zolnikowa I", silnie nasycona treścią kulturową w postaci naczyń i ich fragmentów, artefaktów metalowych oraz licznych kości zwierzęcych; 2) nierówna warstwa żółtej gliny pełniąca formę ,,przekładki” pomiędzy zasadniczymi poziomami użytkowymi kompleksu, w której obrębie nie udokumentowano materiału zabytkowego; 3) zachowana jedynie na obrzeżach obiektu warstwa „zolnikowa II" o analogicznym zabarwieniu i konsystencji jak poziom zalegający niżej (zolnikowa I). Strop tej warstwy został zniszczony przez współczesną działalność agrotechniczną. W chwili obecnej nie sposób precyzyjnie określić wielkości założenia. Uwzględniając układ warstw rozsypiskowych, pierwotną wysokość kompleksu można szacować na ok. 2,4 m (Czopek 2019, 124).

Podczas prac na zolniku pozyskano pokaźną liczbę materiałów archeologicznych. Znaleziska te reprezentuje m.in. ceramika naczyniowa. $\mathrm{W}$ grupie tej obok mało efektywnych, lepionych ręcznie naczyń znajdują się greckie amfory, głównie ich fragmenty (Czopek 2019, ryc. 10), ale także okaz zachowany w całości (ibidem, ryc. 8) i egzemplarze częściowo zrekonstruowane (ibidem, ryc. 11). Zbiór zabytków wykonanych z gliny uzupełniają szpulki - tzw. katuszki (por. np. Bessonowa, Skoryj 2001, 86-87, ryc. 57:10-19; Czopek2019, 133, ryc. 17:8-9), przęśliki, paciorki oraz niewielka figurka antropomorficzna. Wyroby metalowe to głównie militaria (grociki strzał) i ozdoby, w obrębie których wyróżnić można szpile, naszyjniki, pierścionki i drobniejsze aplikacje. Całość dopełniają fragmenty przedmiotów ze złota i liczne kości zwierzęce. Materiały te częściowo zostały już wprowadzone do obiegu naukowego (Czopek 2019; Trybała-Zawiślak 2019; Burghardt 2020). Celem niniejszego artykułu jest dalsze upowszechnianie tych odkryć. Przedstawiono w nim serię szpil pochodzą- cych z badań prowadzonych na zolniku w latach 20172019 oraz podjęto próbę ich uporządkowania i klasyfikacji. Przedmiotem opracowania była również analiza chronologiczna i planigraficzna tych zabytków. $\mathrm{Na}$ ich podstawie podjęto też próbę skonstruowania kilku wniosków na temat chronologii zolnika.

\section{PREZENTACJA ZABYTKÓW ORAZ PODSTAWY ICH KLASYFIKACJI}

Zbiór zabytków sklasyfikowanych jako szpile liczy 21 egzemplarzy (ryc. 1, 2). Uzupełniają go fragmenty trzonów o różnej długości i średnicy przekroju, które z dużą dozą prawdopodobieństwa przypisać można do rzeczonej kategorii zabytków (ryc. 2:12-15). Analogiczna uwaga dotyczy dwóch fragmentarycznie zachowanych podłużnych kościanych przedmiotów o zaostrzonym końcu (ryc. 2:10, 11). Najliczniej wśród szpil reprezentowane są egzemplarze wykonanezbrązu(ryc. 1:1-11;2:1-4,9,12-15), rzadziej zżelaza (ryc. 2:5-8), a tylko wyjątkowo z kości (ryc. 2:10, 11). Obserwujemy również pewne różnice morfologiczne, co upoważnia do ich klasyfikacji typologicznej. Zgodnie $\mathrm{z}$ utrwalonymi w piśmiennictwie archeologicznym systemami klasyfikacji tej grupy zabytków (np. Petrenko 1978; Gedl 1983; Essen 1985) w zbiorze szpil chotynieckich wyróżnić można kilka grup, dla których wyznacznikiem jest kształt główki:

- - szpile gwoździowate (,grzybkowate” - ryc. 1:1-6, 8-11). Należą one do najliczniejszych wśród okazów znalezionych na zolniku. Zaliczone tu egzemplarze różnicuje wielkość, drobne szczegóły morfologiczne oraz obecność i sposób wykonania ornamentu. Łączy surowiec, z którego zostały wykonane - wszystkie okazy to szpile z brązu;

- - szpile o końcach rozklepanych, zwiniętych w uszko, które reprezentują trzy egzemplarze wykonane z żelaza (ryc. 2:5, 7, 8) i jeden z brązu (ryc. 2:9). Ich stan zachowania jest słaby. Okazy żelazne są mocno skorodowane. Do tej grupy zabytków zaliczono również żelazną szpilę pozbawioną główki (ryc. 2:6) $\mathrm{z}$ trzonkiem rozklepanym w górnej części w sposób analogiczny, jak u niektórych zachowanych w całości okazów tego typu;

- - brązowe szpile o jednej (ryc. 2:3) lub dwóch główkach (ryc. 2:1) w postaci tarczek ślimacznicowatych. Poza dwoma kompletnymi egzemplarzami grupę tę reprezentuje najprawdopodobniej również fragment pręta o zaostrzonym końcu i z rozwidleniem w górnej części (ryc. 2:2). Można zasugerować, że 


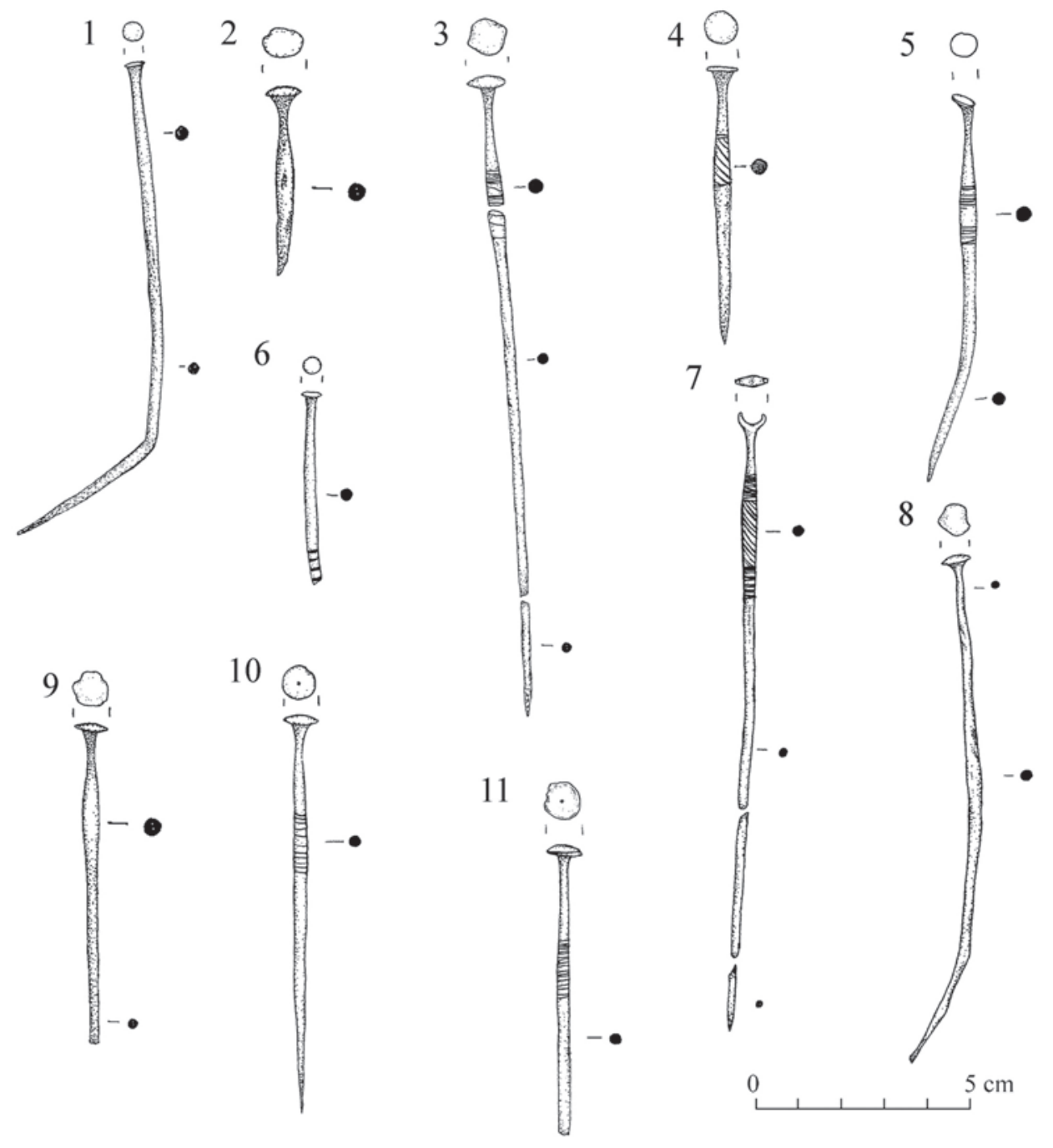

Ryc. 1. Chotyniec, pow. jarosławski, stan. 1. Szpile brązowe. Rys. J. Adamik-Proksa Fig. 1. Chotyniec, Jarosław district, site 1. Bronze pins. Drawing by J. Adamik-Proksa

na zakończeniu każdego ze wskazanych odgałęzień trzonka znajdowała się tarczka spiralna;

- - zrekonstruowana na podstawie fragmentów brązowa szpila z główką w postaci (podwójnie) faliście wygiętego pręta (ryc. 2:4).

Ponadto $\mathrm{w}$ analizowanym materiale udokumentowano wyjątkowy egzemplarz nieposiadający odpowiedników formalnych $\mathrm{w}$ żadnej z opublikowanych do tej pory systematyk szpil. Jest nim brązowy okaz o główce zakończonej rożkowatymi występami (ryc. 1:7).

Bazując na powyższym kryterium, jakim jest kształt główki, można wyróżnić pięć typów szpil. Dodatkowo, biorąc pod uwagę niektóre cechy szczególne (drugorzędne) zabytków przynależących do określonej grupy (typu), w obrębie najliczniejszych z nich wydzielić można kilka podtypów i wariantów.

\section{Typ 1 - szpile z gwoździowatymi główkami}

Do tego typu przyporządkowano 10 szpil. Zaliczone tu okazy charakteryzują się okrągłym w przekroju trzonkiem oraz główką uformowaną na kształt główki gwoździa, przy czym nie wszystkie zachowały się w stopniu umożliwiającym podanie ich wymiarów (odłamanie części trzonka - ryc. 1:2, 6, 9, 11) oraz - w niektórych przypadkach - dokładnych szczegółów stylistycznych (korozja - ryc. 1:8). Kompleksową charakterystykę możemy przeprowadzić jedynie na podstawie pięciu zabytków (ryc. 1:1, 3-5, 10). Cztery szpile $\mathrm{w}$ tej grupie posiadają długość mieszczącą się w przedziale 9-14 cm oraz stosunkowo smukły trzon (ryc. 1:1, 3, 5, 10). Ich waga oscyluje w granicach 4 g, aczkolwiek najdłuższy z egzemplarzy jest nieco cięższy $(5,7 \mathrm{~g})$. Na ich tle wyróżnia się krótki okaz o ma- 
sywnym trzonku (ryc. 1:4). Poza omówionymi wyżej zabytkami grupę szpil gwoździowanych reprezentują też zabytki z odłamaną częścią trzpienia (ryc. 1:2, 6, $9,11)$. Ich stan zachowania jest różny, ale na ogół są one uszkodzone w stopniu nie zezwalającym na podanie chociażby przybliżonych wartości metrycznych i wagowych. Wyjątkiem jest jedna szpila (ryc. 1:8). Ze względu na odłamanie jedynie końcówki dolnej części trzonka zasugerować można, że egzemplarz ten miał co najmniej $12 \mathrm{~cm}$ długości i wagę nieco ponad $4 \mathrm{~g}$ (zachowane wartości: długość - 11, $5 \mathrm{~cm}$; waga $-4,1 \mathrm{~g})$.

Omawiane zabytki różnicuje też kilka szczegółów morfologicznych, m.in. kształt główki. Jej górna część w przekroju poprzecznym przybiera kształt lekko wypukły, grzybkowaty (ryc. 1: 2, 3, 5, 8-11), bądź też płaski gwoździowaty (ryc. 1: 1, 4,6), stąd też w nomenklaturze zabytków o takiej kwalifikacji funkcjonalnej przymiotniki te używane są zamiennie jako podstawa nazewnictwa typu (por. Petrenko 1978, 7). Dodatkowo w morfologii szpil chotynieckich dostrzec można pewne różnice w formie trzonka, który może być prosty (ryc. 1:1, 4, 6, 8, 10, 11) lub lekko pogrubiony w środkowej lub górnej części (ryc. 1:2, 3, 5,9). Kolejnym elementem, który różnicuje okazy o takiej przynależności stylistyczno-typologicznej jest ornament. Na dziesięć analizowanych tutaj przypadków aż sześć jest zdobionych (ryc. 1:3-6, 10,11), trzy nie posiadają dekoracji (ryc. 1:1, 2, 9), a o stylistyce jednego z nich nie można nic powiedzieć, ponieważ zabytek ten jest bardzo silnie skorodowany (ryc. 1:8). Sam ornament jest też zróżnicowany. Niektóre ze szpil zdobione są poziomymi kreskami (np. ryc. 1:11), podczas gdy inne posiadają bardziej rozbudowaną ornamentykę, skomponowaną z nacięć poprzecznych i poziomych (ryc. 1:4). Daje się również zauważyć pewne różnice w sposobie wykonania ornamentu (delikatne nacięcia - np. ryc. 1:5, głębokie ryty, między którymi powstaje rodzaj wybrzuszenia - ryc. 1:6).

Powyższe informacje pokazują, że chotynieckie szpile gwoździowate nie są grupą jednolitą. Opierając się na różnicach w zakresie cech metrycznych, morfologicznych i stylistycznych analizowanych ozdób, można dokonać ich klasyfikacji na kilka podtypów i wariantów. Dla kwestii tej duże znaczenie ma praca V.G. Petrenko pt. Ukrašenija Skifii VII-III vv. do n.č. (1978), na której łamach autorka podjęła próbę usystematyzowania podobnych zabytków oraz podała podstawowe informacje na temat ich rozprzestrzenienia i chronologii. Zastosowany przez nią schemat charakterystyki szpil z grzybkowatą główką w pełni oddaje specyfikę okazów chotynieckich, dlatego zaadoptowano go do zaprezentowania ich opisu w bardziej uporządkowanej formie. Na jego podstawie wyróżniono pięć podtypów, których opis przedstawiono poniżej. Skróconą charakterystykę szpil z uwzględnieniem poszczególnych podtypów i wariantów w obrębie danej grupy typologicznej wraz z odnośnikami do tablic oraz ich odpowiednikami w typologii, na której bazowano, zaprezentowano też w tabeli 1 .

Podtyp 1 (I/1). W tym podtypie znalazły się dwie szpile ze spłaszczoną główką, łukowato wygiętą szyjką oraz okrągłym w przekroju trzonkiem, który zdobiony jest zwielokrotnionym układem poziomych nacięć (ryc. 1:4, 6). W klasyfikacji V.G. Petrenko analogiczne okazy zakwalifikowane zostały do typu 4 (1978, 8, 11, 12). Zróżnicowanie wewnętrzne w zbiorze przedmiotów o takiej przynależności typologiczno-stylistycznej opiera się na różnicach w dekoracji oraz rozmiarach zabytków. Ze względu na te cechy wyróżnić możemy dwa warianty:

- wariant a (I/1/a). Szpila o małej płaskiej główce (średnica $-4 \mathrm{~mm}$ ) oraz prostym, okrągłym w przekroju trzonie (średnica $-3 \mathrm{~mm}$ ) z ornamentem usytuowanym w połowie jego wysokości (?). Egzemplarz posiada kilka głębokich dookolnych rowków (ryc. 1:6). Szpila wariantu „a” typu I odpowiada drugiemu wariantowi typu 4 w klasyfikacji zabytków znad środkowego Podnieprza (por. V.G. Petrenko 1978, 8);

- wariant b (I/1/b). Krótka (długość $-6,3 \mathrm{~cm}$ ) szpila o szerokiej główce (średnica $-8 \mathrm{~mm}$ ). Jest to egzemplarz charakteryzujący się rozbudowaną dekoracją. Kompozycję motywów zdobniczych tworzą tu ukośne żłobki, usytuowane pomiędzy poziomymi nacięciami (ryc. 1:4). Podobna forma została zaliczona przez V.G. Petrenko do wariantu 6 typu IV $(1978$, tabl. 2:20), przy czym różniła się ona od wyżej opisanej rodzajem zastosowanego ornamentu.

Podtyp 2 (I/2). Tworzy go egzemplarz o lekko wysklepionej „grzybkowatej” główce. Szyja ma stożkowatą formę, a jej krawędzie łączą się z brzegiem główki. Trzonek jest pogrubiony w górnej części (ryc. 1:2). Odpowiednikiem tej formy są egzemplarze zaliczone przez V.G. Petrenko do typu $6(1978,13)$. Wymiary: zachowana długość $-4,2 \mathrm{~cm}$, średnica główki $-9 \mathrm{~mm}$, największa średnica trzonka $-4 \mathrm{~mm}$.

Podtyp 3 (I/3). Szpile o wysklepionej (grzybkowatej) główce, łukowato ukształtowanej szyi i trzonie zawierającym owalne zgrubienie powyżej połowy 


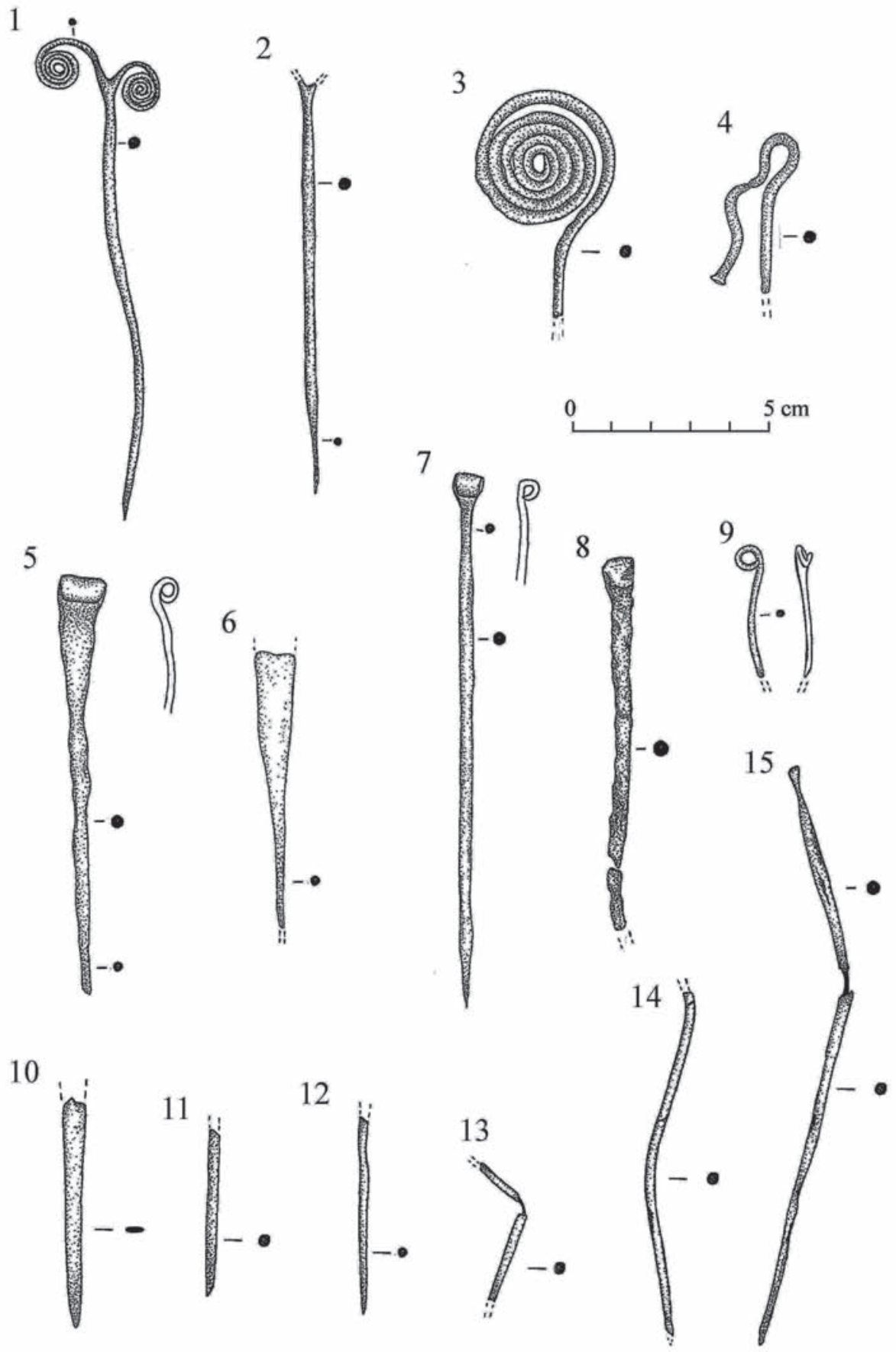

Ryc. 2. Chotyniec, pow. jarosławski, stan. 1. Szpile brązowe (1-4, 9, 12-15), żelazne (5-8) i kościane $(10,11)$. Rys. J. Adamik-Proksa

Fig. 2. Chotyniec, Jarosław district, site 1. Bronze pins (1-4, 9, 12-15), iron pins (5-8), bone pins $(10,11)$. Drawing by J. Adamik-Proksa

swojej wysokości, wyodrębniono jako kolejną jednostkę porządkującą (podtyp). Formy takie znajdują analogie w typologii V.G. Petrenko wśród okazów zakwalifikowanych przez badaczkę do typu 10. Zaliczone tu zabytki są zróżnicowane pod względem stylistycznym, co upoważnia do wydzielenia kilku wariantów:
- wariant a (I/3/a). Niezdobiona szpila $\mathrm{z}$ wyraźnym owalnym zgrubieniem (największa średnica trzonka $-4 \mathrm{~mm}$ ) w górnej części, pod szyjką (ryc. 1:9). Główka szpili jest stosunkowo duża-ok. $10 \mathrm{~mm}$. Egzemplarzowi wariantu „a” podtypu 3 odpowiadają 
szpile wariantu drugiego typu $10 \mathrm{w}$ klasyfikacji zabytków znad środkowego Podnieprza (ibidem,14);

- wariant b (I/3/b). Obejmuje w tej klasyfikacji dwie szpile nawiązujące pod względem formalnym do wariantu ,a”, przy czym są to okazy ornamentowane na pogrubionej części trzonka. Dekoracja ma postać dookolnych nacięć, które występują w układzie ciągłym bezpośrednio $\mathrm{w}$ strefie pogrubienia (ryc. 1:3), bądź też w dwóch grupach usytuowanych na jego krawędziach (ryc. 1:5). Dodatkowo, pomiędzy zaliczonymi tutaj okazami widoczne są pewne różnice w długości trzonów i średnicy główek. Okaz zdobiony wątkiem zwielokrotnionych rytów posiada dużą, grzybkowatą nasadę o średnicy $10 \mathrm{~mm}$ i długość $14,1 \mathrm{~cm}$. Szpila z dekoracją w postaci dwóch rzędów nacięć jest krótsza (długość - $9 \mathrm{~cm}$ ), a średnica jej główki wynosi zaledwie $6 \mathrm{~mm}$. W systematyce V.G. Petrenko opisanym wyżej przypadkom odpowiadają szpile wariantu 3, typu 10.

Podtyp 4 (I/4). Trzy szpile o wypukłej grzybkowatej główce i łukowatej szyjce, która została osadzona na prostym trzonku, posiadającym zdobienie w postaci spirali złożonej z kilkunastu zwojów (ryc. 1:8, 10, 11). Główka szpil ma średnicę 9-10 mm, długość zabytków na podstawie egzemplarzy zachowanych w całości (ryc. 1:8, 10) można oceniać w granicach 9-11,5 cm. W klasyfikacji V.G. Petrenko brązowe szpile o takiej formie uznawane są za wyznacznik typu 11 $(1978,14)$. Dekoracja w postaci wielozwojowej spirali jest cechą charakterystyczną dla wariantu 3.

Podtyp 5 (I/5). Szpila z małą płaską główką, łukowatą szyjką i prostym (niepogrubionym) trzonkiem (ryc. 1:1). Wymiary: długość - 12,2 cm, średnica głów$\mathrm{ki}-5 \mathrm{~mm}$. W systematyce szpil V. G. Petrenko okazy o takich cechach zaliczone zostały do typu 5 .

\section{Typ II - szpile o końcach rozklepanych i zwiniętych w uszko}

Drugi pod względem liczebności typ szpil skupia pięć okazów o końcu mniej lub bardziej rozklepanym i zwiniętym w uszko (ryc. 2:5-9). Wykaz ten uzupełnia fragment silnie skorodowanego żelaznego przedmiotu, który najprawdopodobniej również należy łączyć $\mathrm{z}$ tą jednostką typologiczną. Podstawowymi cechami różnicującymi zabytki w tej grupie są: surowiec (żelazo lub brąz) oraz wielkość. Charakterystyczne jest to, że egzemplarze wykonane z żelaza są stosunkowo duże i masywne. Długość okazu zachowanego w całości wynosi $13 \mathrm{~cm}$ (ryc. 2:7). W przypadku żelaznych szpil z odłamaną dolną częścią trzonka można oceniać, że nie były one krótsze niż $10 \mathrm{~cm}$ (tyle wynosi ich zachowana długość). Nie miej istotna jest tutaj grubość trzpienia, która w przypadku omawianych zabytków wynosi od 5 do $3 \mathrm{~mm}$. W przeciwieństwie do egzemplarzy żelaznych, szpila wykonana z brązu jest niewielka, można ją wręcz uznać za okaz „miniaturowy". Jej wymiary to: zachowana długość $-3,2 \mathrm{~cm}$, średnica nóżki $-2 \mathrm{~mm}$. Korelując relacje zachodzące między wyżej omówionymi parametrami w zbiorze chotynieckich szpil o końcach rozklepanych i zwiniętych w uszka, można wydzielić dwa podtypy. Podobne kryteria podziału zastosowała V.G. Petrenko $(1978,18)$.

Podtyp 1 (II/1). Podtyp ten reprezentowany jest przez cztery egzemplarze wykonane z żelaza (ryc. 2:5-8). Najprawdopodobniej z grupą tą należy także łączyć fragment podłużnego skorodowanego przedmiotu znaleziony na zolniku. Okazy podtypu II/1 odpowiadają szpilom wariantu 1 typu 21 w klasyfikacji V.G. Petrenko. Ich formalne odpowiedniki są też obecne w propozycji systematyki szpil o końcu rozklepanym i zwiniętym w uszko autorstwa Łukasza Niemca, gdzie egzemplarze żelazne analogiczne do okazów chotynieckich przyporządkowane zostały do typu II (Niemiec 2006, 127-130). Wymiary: szerokość główki - 8-10 mm, średnica trzonka - 3-5 mm, długość szpili zachowanej w całości - 13,1 cm.

Podtyp 2 (II/2). Pojedynczy egzemplarz brązowej szpili o główce ukształtowanej na wzór ucha, które powstało poprzez lekkie rozklepanie i zakręcenie jednego z końców trzonka w pętelkę (ryc. 2:9). Przekrój drutu jest zróżnicowany - czworoboczny w części główki oraz okrągły na długości nóżki. Wymiary: szerokość główki $-8 \mathrm{~mm}$, średnica trzonka $-2 \mathrm{~mm}$, zachowana długość okazu $-3,2 \mathrm{~cm}$. Waga $-0,7 \mathrm{~g}$. Szpila typu II/2 posiada swoje odpowiedniki w wielokrotnie już przytaczanej klasyfikacji scytyjskich szpil autorstwa V.G. Petrenko (1978, 18, np. tabl. 12:9). W systematyce tej odpowiadają jej okazy wariantu 2 typu 21, który grupuje niewielkie szpile (długość 5-6 cm) o niewyodrębnionej, jednozwojowej główce.

\section{Typ III - szpile o główkach w postaci tarczek ślimacznicowatych}

Typ trzeci tworzą, wykonane $\mathrm{z}$ brązowego drutu, szpile z główkami w formie spiralnych tarczek. Biorąc pod uwagę liczbę główek egzemplarzy przy- 
porządkowanych do tego typu, można wydzielić dwa podtypy:

Podtyp 1 (III/1). Niezdobiona szpila o główce $\mathrm{w}$ formie pojedynczej płaskiej tarczki ślimacznicowatej (ryc. 2:3). Liczba zwojów w tarczce wynosi 5,5. Zarówno główka, jak i trzon zabytku zostały wykonane z drutu o przekroju okrągłym. Wymiary: szerokość główki $-3,5 \mathrm{~cm}$, średnica trzonka $-3 \mathrm{~mm}$, zachowana długość okazu $-5,5 \mathrm{~cm}$. Waga - 9,6 g. Dla szpili typu III/1 formalnym odpowiednikiem są ozdoby typu 22 według V.G. Petrenko (1978, s. 18-19).

Podtyp 2 (III/2). Szpila o zwielokrotnionej tarczce spiralnej (ryc. 2:1). Egzemplarz charakteryzuje się okrągłym trzonem oraz główką w postaci dwóch tarczek o czworobocznym przekroju. Do omawianej grupy zabytków zaliczono też jeden okaz bez główki (ryc. 2:2). Na podstawie charakterystycznego rozwidlenia trzonka w górnej części, można z bardzo dużym prawdopodobieństwem założyć, że również i on posiadał taką formę. Omawiane tu zabytki nawiązują do szpil o dwóch, czterech lub sześciu tarczkach spiralnych, które tradycyjnie kojarzy się z wyrobami tzw. kujawskiego ośrodka metalurgicznego (Kostrzewski 1953, 38; Cofta-Broniewska, Hensel 1996, 54-56). Wymiary szpili zachowanej w całości: szerokość tarczek w główce - 10 i $13 \mathrm{~mm}$, średnica trzonka $-3 \mathrm{~mm}$, długość $-12 \mathrm{~cm}$. Waga $-4,2 \mathrm{~g}$.

\section{Typ IV - szpila o główce w formie faliście wygiętego pręta}

Podtyp 1 (IV/1). Szpila o dość specyficznej formie, $\mathrm{z}$ główką w postaci podwójnie zagiętego pręta (ryc. 2:4). Górna część drutu tworzącego okaz jest dwukrotnie zakrzywiona (załamana), co nadaje główce kształt falisty. Zakończenie pręta stanowiącego przedłużenie główki jest nitowane. Szpilę wykonano z brązowego drutu o przekroju okrągłym. W systematyce szpil z obszaru środkowego Podnieprza autorstwa V.G. Petrenko egzemplarze o podobnie uformowanej główce zaliczone zostały do typu 24, który skupia oprócz okazów analogicznych do szpili z Chotyńca także egzemplarze z aplikacjami zoomorficznymi (por. Petrenko 1978, 19). Wymiary: szerokość główki-2,5 cm, średnica trzonka - $3 \mathrm{~mm}$, zachowana długość okazu $-4,2 \mathrm{~cm}$. Waga $-1,8 \mathrm{~g}$.

\section{Typ V - szpila o główce zakończonej rożkowatymi występami}

Podtyp 1 (V/1). Szpila o końcu rozdwojonym i tworzącym rogi, zdobiona w górnej części trzonka rozbudowaną kombinacją żłobków poprzecznych i poziomych (ryc. 1:7). Szpila ta jest zabytkiem wyjątkowym, nie posiadającym odpowiedników formalnych $\mathrm{w}$ systematykach szpil z wczesnej epoki żelaza. Wymiary: szerokość główki - $6 \mathrm{~mm}$, największa średnica trzonka $-3 \mathrm{~mm}$, długość okazu $-14,2 \mathrm{~cm}$. Waga $-4,4$ g.

Poza klasyfikacją znalazły się formy niekompletne, głównie fragmenty trzonków. Wśród nich odnotowano zarówno przedmioty z brązu (ryc. 2:12-15), jak i z kości (ryc. 2:10, 11). Ze względu na brak główki okazów tych nie można zaliczyć do któregoś z wyżej wymienionych typów. Wyjątek stanowi egzemplarz (ryc. 2:15) z charakterystycznym zgrubieniem na trzonku. Cecha ta sugeruje związek omawianego okazu ze szpilami gwoździowatymi odmiany I/2 lub I/3.

\section{ANALIZA TYPOLOGICZNO-CHRONOLOGICZNA SZPIL - PRÓBA OKREŚLENIA RAM CZASOWYCH FUNKCJONOWANIA ZOLNIKA}

Próbę oceny chronologicznej omawianych zabytków, a tym samym oszacowania datowania zolnika rozpoczniemy od analizy typologiczno-porównawczej. Jak wskazano powyżej, materiał pozyskany w trakcie eksploracji zolnika dostarczył kilku typów szpil. Wśród nich najliczniejsze są egzemplarze sklasyfikowane w obrębie typu 1, tj. szpile o gwoździowatej główce. Reprezentują one kilka podtypów, których chronologię odnosić należy przede wszystkim do końca VII i VI w. p.n.e. Zgodnie z propozycjami V.G. Petrenko (1978) za jeden z najstarszych zabytków w tej grupie uznać należy egzemplarz z nieznacznie wysklepioną główką, łukowatą szyjką, której krawędzie łączą się z główką i trzonem zawierającym owalne zgrubienie w górnej części (ryc. 1:2). Rzeczona forma, która w klasyfikacji zabytków chotynieckich reprezentuje podtyp 2 (I/2), nawiązuje do szpil typu 6 w typologii badaczki, będących jedną z najstarszych form, na co ma wskazywać ich współwystępowanie dopiero z zabytkami z końca VII - początku VI w. p.n.e. $(1978,13)$. Ścisłe analogie do wzmiankowanego okazu z Chotyńca, stan. 1 można zaobserwować 
w zbiorze z miejscowości Żabotin oraz ze wsi Chreszczatyk (Petrenko 1978, tabl. 7:1, 2). M. Daragan przyporządkowała podobne okazy do typu 3, który skupia oprócz zabytków typu 6 wg V.G. Petrenko, również egzemplarze zaliczone przez nią do typu 3, tj. szpile z płaską główką, łukowatą szyjką i trzonkiem z pogrubieniem w górnej części (Petrenko 2011, tabl. IV, $52: 14,15)$. Omówiony typ szpil jest zdaniem badaczki elementem charakterystycznym dla zestawu zabytków fazy Żabotin III (ibidem, ryc. V:1) synchronizowanej z przedziałem czasu od końca VIII do 1. poł. VII w. p.n.e (ibidem, 779, ryc. V:88). W te ramy czasu dobrze wpisuje się też analogia z warstwy A2 zolnika 5 z grodziska Bilskiego (Shramko 2006, ryc. 12:4), której pozycję chronologiczną ustalono na podstawie współwystępowania z innymi przedmiotami datującymi, m.in. z romboidalnym grocikiem typu EndzheZhabotin na 2. ćwierć VII w. p.n.e. (ibidem, 42).

Do omówionego wyżej zabytku, ze względu na cały zespół cech formalnych, takich jak: kształt główki, obecność zgrubienia w górnej części trzonu i brak ornamentacji, nawiązuje szpila sklasyfikowana w ramach wariantu ,a" trzeciego podtypu (I/3/a ryc. 1:9). Różni się natomiast sposobem uformowania szyjki. Wskazany zabytek wraz ze swoimi odpowiednikami w wersji ornamentowanej (wariant b - ryc. $1: 3,5)$ nawiązuje do form typu $10 \mathrm{wg}$ V.G. Petrenko, których datowanie przypada na koniec VII - początek VI w. p.n.e (1978, 14). Egzemplarz niezdobiony (ryc. 1:9) stanowi wierne naśladownictwo okazów wariantu drugiego i trzeciego w typologii badaczki. Niemal identyczne formy znalezione zostały na wydmach obok wsi Lichaczówka (ibidem, tabl. 7:15), w rejonie Kaniewskim (ibidem, tabl. 7:14) oraz w okolicy Rzyszczewa (ibidem, tabl. 7:16). Niezdobiona szpila o podobnej formie (zgrubienie w górnej partii trzpienia), aczkolwiek z płasko uformowaną główką pochodzi też z osady otwartej w Hruszowicach, stan. 2 (Czopek et al. 2018, ryc. 9.20:1), która wespół z grodziskiem w Chotyńcu i innymi obiektami w sąsiedztwie wchodzi w skład mikroregionu osadniczego zwanego aglomeracją chotyniecką (ibidem, 197n). Na uwagę zasługuje fakt, że jest to zabytek odnoszony do VII i VI w p.n.e. Jeżeli chodzi o ornamentowane szpile odmiany I/3, to w klasyfikacji V.G. Petrenko (1978) można je wiązać z czwartym wariantem typu 10. Nasze egzemplarze są najbardziej zbliżone do szpili z Bilskiego grodziska (ibidem, tabl. 7:17).

W trakcie eksploracji zolnika znaleziono również szpile brązowe o wypukłej grzybkowatej główce, zdobione ornamentem $\mathrm{w}$ postaci spirali na prostym niepogrubionym trzonku (ryc. 1:8, 10, 11), które sklasyfikowano w ramach podtypu 4. Wspomniane okazy należą do dużej grupy szpil o wysklepionej główce, łukowato uformowanej szyjce i okrąłym w przekroju ornamentowanym trzonie - typ $11 \mathrm{wg}$ V.G. Petrenko (por. 1978, 14). Zabytki o takiej przynależności typologicznej na ogół zdobione są rozbudowaną kompozycją wątków dekoracyjnych, którą tworzą dwie grupy rytów i usytuowane między nimi owalne lub dwustożkowate zgrubienie (warianty 1 i 2). Nasze szpile nawiązują jednak do wariantu, charakteryzującego się bardziej oszczędną dekoracją (wariant 3 - spirala złożona z 2-9 zwojów). Manifestuje on swoją obecność w zespołach, których chronologia przypada na koniec VII - VI w. p. n. e. (ibidem 1978, 14), np. na osadach i w obiektach grobowych grupy zachodniopodolskiej, najbliższej terytorialnie w stosunku do Chotyńca. Identyczne do podtypu 4 okazy znane są np. z miejscowości Doliniany, gdzie wystąpiły w zbiorze z wykopu 4, który uznano za homogeniczny zestaw źródeł i datowano na podstawie ceramiki greckiej na VI lub 2. połowę VI w. p.n.e. (Smirnova 1981, 44, 56n, ryc. $6: 1,2 ; 2004$, ryc. 5:19, 20). Dobry odpowiednik stanowi też szpila z kurhanu nr 4 z Malinivki, którego datowanie przypada na koniec VII - początek VI w. p.n.e. (Gucal et al. 2004, 116, ryc. 2:9). Poza terytorium grupy zachodniopodolskiej szpile o omawianej formie występują także wśród społeczności grupy pawobrzeżnej, worsklańskiej i posulskiej (Petrenko 1978, 14). Najbardziej zbliżone formalnie do egzemplarzy serii chotynieckiej są zabytki z cmentarzyska koło uroczyska Skorobor w rejonie Bilskiego grodziska (Petrenko 1978, tabl. 7:26) oraz grodzisk Trachtimirowskie (ibidem, tabl. 9:19) i Basowskie (ibidem, tabl. 9:21). Znamy je też z zasięgu kultury wysockiej (Sulimirski 1936, tabl. XXV:17) oraz Starego Machnowa, który położony jest w stosunkowo niedalekiej odległości (ok. 80 km na północny-wschód) od Chotyńca (Kłosińska 2010, ryc. 2:2; 2013).

Młodszą pozycję w stosunku do opisanych wyżej egzemplarzy ze zgrubieniem na trzonku pod nasadą główki (podtypy 2 i 3) oraz szpil z wysklepioną (grzybkowatymi) górną częścią i trzonkiem zdobionym ornamentem w postaci spirali (podtyp 4) posiadają formy o płaskiej główce, łukowatej szyjce i nóżce z grupami dookolnych nacięć (ryc. 1:4,6). Szpile te nawiązują do form typu IV w systematyce zabytków z obszarów środkowego Podnieprza. Jest to duża grupa szpil, które rozpowszechnione są w wielu odmianach (Petrenko 1978, 8, 11-12), przy czym dopiero od VI w p.n.e. Uszkodzony egzemplarz z głębokimi żło- 
bieniami (ryc. 1:6) odpowiada wariantowi drugiemu, ewentualnie piątemu w klasyfikacji wielokrotnie już wspominanej badaczki, które to odmiany nota bene różnicuje jedynie ornamentyka i niewielkie szczegóły morfometryczne (np. grubość trzonka). Nasz okaz nie jest kompletny, przez co trudno opowiedzieć się za jedną z opcji, aczkolwiek masywny trzonek oraz strefa usytuowania dekoracji sugerują jego związek $\mathrm{z}$ drugim wariantem. Znamy podobnie uformowaną szpile z kurhanu nr 73 z miejscowości Kurilovka (Kovpanenko 1981, ryc. 25:3). Analogiczne formy, na ogół z tzw. ornamentem na „dżdżownicę" (por. Daragan 2010; Kowalski-Biłokryłyy 2012, 162-163), pochodzą też z wydm w miejscowości Lichaczówka (Petrenko 1978, tabl. 1:35-37), czyli z zasięgu tzw. grupy worsklańskiej. Takie same ramy czasowe ustalono dla szpil rodzaju piątego (ibidem 1978, 11).

Innym wariantem szpili typu I jest krótki okaz $(6,3 \mathrm{~cm})$ o stosunkowo masywnym $(4 \mathrm{~mm})$ trzonie i szerokiej główce (ryc. 1:4). Jego formalnym odpowiednikiem, aczkolwiek różniącym się drobnymi szczegółami - ornament, jest szpila z zachodniego członu grodziska Bilskie (Shramko 1987, ryc. 11:2), którą V.G. Petrenko wydzieliła jako osobny wariant (1978, 11, tabl. 2:20). Rzeczony zabytek pochodzi z ziemianki datowanej na początek VI w. p.n.e. (Shramko 1987, 279).

Zapewne także z VI w. p.n.e. pochodzi szpila z małą płaską główką, łukowatą szyjką i prostym (niepogrubionym) trzonkiem podtypu 5 (ryc. 1:1). Okazy do niej podobne, tj. szpile typu 5 wg V.G. Petrenko, występują na całym terytorium lasostepu (1978, 12-13). Dobrym odpowiednikiem dla zajmującej nas odmiany szpil jest okaz znaleziony w warstwie kulturowej kompleksu 1 na grodzisku Severynivka, której chronologię na podstawie zdeponowanych w niej artefaktów oceniono na VI w. p.n.e. (Lifantii, Sheleckhan 2016, 258, ryc. 1:37). Do tego samego typu przynależą też dwa analogiczne okazy pozyskane $\mathrm{z}$ tego stanowiska podczas wykopalisk B.M. Lobay w 1980 roku (ibidem 2016, ryc. 1:57, 59). Pod względem formalnym „chotynieckiemu” okazowi odpowiada także brązowa szpila z obiektu mieszkalnego nr 2 ze stanowiska Doliniany (Smirnova 1981, ryc. 6:16), przy czym nasz egzemplarz różni się nieco od wskazanego zabytku uformowaniem trzonka (brak lekkiego pogrubienia). Nie wyklucza to jednak jego klasyfikacji w ramach tego samego typu, bowiem nieco pogrubiony w środkowej części trzon jest zdaniem V.G. Petrenko nie kryterium formalnym, a elementem charakterystycznym dla określonego terytorium
- grupy zachodniopodolskiej (1978, 12). Chronologię szpili z miejscowości Doliniany na podstawie współwystępujących z nią w zespole fragmentów antycznej ceramiki należy odnosić do VI w. p.n.e. (por. Smirnova 1981, 41, 56n). Powyższe obserwacje konweniują z ustaleniami V.G. Petrenko, że szpile typu 5 pojawiają się dopiero od VI w. p.n.e. (ibidem, 13).

W naszkicowanym powyżej przedziale czasu (VII-VI w. p.n.e.) mieści się również okres funkcjonowania pozostałych typów szpil. Uwaga ta dotyczy m.in. odmiany z główką w formie spiralnej tarczki (typ III/1 - ryc. 2:3), która w klasyfikacji V.G. Petrenko odpowiada okazom typu 22 . Na terenach położonych na wschód od Chotyńca, w strefie ukraińskiego lasostepu, a konkretnie jego zachodnich rubieży ozdoby o analogicznej formie spotykane są stosunkowo często. Znamy je m.in. z osad w miejscowości Doliniany (Smirnowa 1981, ryc. 6:4;2004, ryc. 5:8,9,12), Żabotin (Petrenko 1978, tabl. 13:13), grodziska Severynivka (Lifantii, Shelekhan 2016, tabl. I:60) oraz z obiektów grobowych, np. kurhany Rokovkat (kurhan 1 - Petrenko 1978, tabl. 13:15, 17), Bratyszów (kurhan 3 - Sulimirski 1936, 53, tabl. VIII:3a) i Tenetikowska mogiła nr 136 (Petrenko 1978, tabl. 13:14; Klochko 2016, ryc. 6:6). Wymienione zespoły są datowane stosunkowo wcześnie - koniec VII - początek VI w. p.n.e. Analogie do szpil brązowych z tarczką spiralną pochodzą również ze stanowisk kultury wysockiej (Sulimirski 1931, 134, tabl. XXIV:24, 25; XXV:17; Gawlik 2005, ryc. 3:1, m). Trzeba też odnotować obecność takich form na terenach ziem polskich, np. na osadach scytyjskiego kręgu kulturowego zlokalizowanych w sąsiedztwie Chotyńca (Hruszowice, stan. 2 i Nienowice, stan. 24 - Czopek et al. 2018, ryc. 9.20:3, 9.35:6) oraz na cmentarzyskach łączonych z wczesnym (np. Czopek 1996, tabl. XXXIII:14) i późnym stadium rozwoju tarnobrzeskiej kultury łużyckiej (Moskwa 1976, ryc. 33; Trybała-Zawiślak 2012, tabl. VI:10). Inną ważną informacją jest ta, że zdaniem V.G. Petrenko to właśnie kontakty z środowiskiem łużyckim przyczyniły się upowszechnienia omawianych zabytków $\mathrm{w}$ inwentarzach zachodnich ugrupowań wczesnoscytyjskich (1978, 18-19). Wielce znacząca w tym kontekście jest obecność takich form na ziemiach polskich już w epoce brązu, warto jednak zwrócić uwagę na pewne różnice $\mathrm{w}$ formie szpil tarnobrzeskich i okazów „wschodnich”. Szpila z Chotyńca, podobnie jak większość okazów wczesnoscytyjskich, wykonana została z okrągłego drutu. Typowe tarnobrzeskie okazy mają czworokątny przekrój drutu w strefie główki (por. Moskwa 1976, 21). 
Do listy zabytków, których chronologia pokrywa się z datowaniem omówionych już artefaktów, należy też dopisać szpile o główce w formie dwóch tarczek ślimacznicowatych (ryc. 2:1,2). Trzeba jednak zaznaczyć, że w przeciwieństwie do większości okazów gwoździowatych ozdoby tego typu wykazują nieco dłuższą chronologię, przypadającą na cały młodszy okres halsztacki (Blajer 2001, 67, ryc. 34), co w tradycyjnym ujęciu mieści się w przedziale 650 530/510 p.n.e. (Trachsel 2004). Dla omawianego typu nietrudno znaleźć analogie wśród dotychczas opublikowanych materiałów. Niezwykle istotny jest fakt, że zabytki takie współwystępują z innymi znanymi z Chotyńca materiałami (np. szpile gwoździowate) w zespołach osadowych (np. Doliniany - Smirnowa 2004, ryc. 5:7) oraz grobowych (np. Teklivka, kurhan 3 - Gucal et al. 2003, ryc. 1:4; Lisiczniki - Smirnowa 2004, ryc. 6:2) najbliższej terytorialnie jednostki kręgu scytyjskiego, tj. w grupie zachodniopodolskiej. Znamy je też z Wielkopolski, gdzie traktowane są jak wytwór tzw. kujawskiego ośrodka metalurgicznego (Cofta-Broniewska, Hensel 1996, 54-56). Natomiast tylko wyjątkowo pojawiają się w materiałach tarnobrzeskiej kultury łużyckiej (Trybała-Zawiślak 2012, 165, tabl. XXXV:7).

Zabytkami, które nie wnoszą wiele do ustaleń chronologicznych, są szpile o rozklepanej, zwiniętej w uszko główce (ryc. 2:5-9). Ten typ pojawia się już w starszym etapie epoki brązu (Dąbrowski 2004, 34, ryc. 46b) i w ciągu II tysiąclecia $\mathrm{BC}$ rozpowszechnia się $\mathrm{w}$ trzcinieckim kręgu kulturowym, kulturze mogiłowej i wczesnych kontekstach łużyckich (Essen 1985, np. tabl. 18:426-430), po czym manifestuje swoją obecność również we wczesnej epoce żelaza (np. Czopek 1996, 18). Podobna sytuacja dotyczy też obszarów położonych na wschód od Chotyńca, gdzie omawiane formy prócz wspomnianego terytorium „trzcinieckiego” reprezentują też takie ugrupowania jak kultury sabatinowska, Noua i biełozierska (Lysenko, Lysenko 2019, 161-162), a w późniejszym okresie również zespoły scytyjskie (np. Petrenko 1978, 18, tabl. 13:1-7; Andrienko 1996, 357, ryc. 1:1,2; Klochko 2016, ryc. 6:4). W związku z powyższym, zajmujące nas szpile nie mogą być brane pod uwagę jako podstawa dla bardziej szczegółowych uściśleń chronologicznych, przy czym należy mieć na uwadze, że swoisty walor „datownika” posiada surowiec, z którego zostały wykonane. Uwaga ta dotyczy jednak wyłącznie ozdób żelaznych, które, jak można przypuszczać, na terenie południowo-wschodniej Polski upowszechniły się w młodszej części okresu halsztackiego (Czopek 1992, 111n; Niemiec 2006, 126130). Zabytki podobne do typu II/1 występują dość powszechnie w materiałach tarnobrzeskiej kultury łużyckiej w fazie III1, datowanej na okres HaD2-HaD3 (ibidem). W tym samym czasie występują też na terytorium Ukrainy, czego dobrym przykładem jest szpila z grodziska Severynivka (Lifantii, Shelekhan 2016, 256 , ryc. 1:44).

Bardzo ciekawym zabytkiem jest druga odmiana wyżej opisanych form, a mianowicie brązowa szpila typu II/2 (ryc. 2:9), nawiązująca do małych okazów typu 21 (wariant 2) wg V.G. Petrenko (1978, tabl. 12:8-28) lub form pierwszego wariantu typu $3 \mathrm{wg}$ D.S. Grechko (2010, 87, tabl. 76:1-3, 77:1-5). Jest to grupa zabytków, których ramy chronologiczne są dość szerokie. W zespołach leśnostepowych ugrupowań omawiana kategoria ozdób obecna jest w przedziale VI-III w. p.n.e. Przedmioty takie pojawiają się również w zespołach stepowych, których chronologia przypada na okres IV-III w. p.n.e. (Petrenko 1978, 18). Fakt, iż są to wyłącznie stanowiska o charakterze osadowym, dodatkowo utrudnia zawężenie ich datowania. Warto nadmienić, że V.G. Petrenko zwraca uwagę na związek omawianych form z grupą worsklańską. W przeciwieństwie do nich scharakteryzowane wyżej zabytki odmiany II/1 występują we wczesnych kontekstach i to głównie na obszarach prawobrzeżnego Podnieprza.

Do grupy szpil wyjątkowych zaliczyć można egzemplarz o główce w postaci faliście wygiętego pręta (ryc. 2:4). Analizowany okaz nawiązuje do szpil typu 24 wg V.G. Petrenko, które zdaniem badaczki nie należą do zabytków zbytnio rozpowszechnionych i występują głównie w grobach przedstawicieli arystokracji scytyjskiej w strefie stepu (Petrenko 1978, 19, tabl. 14:14-21). Sporadycznie w pojedynczych egzemplarzach pojawiają się też na grodziskach, np. Kamieńske w strefie stepowej (Klochko 2007, ryc. 10) lub Matronińskie na obszarze leśnostepowego prawobrzeżnego Podnieprza. Stwierdzono też obecność podobnych zabytków w kulturze miłogradzkiej (por. ibidem, 37). Należy tutaj zaznaczyć, że ozdoby takie w literaturze przedmiotu traktowane są jako oznaki prestiżu. Niekiedy przypisuje się im funkcje symboliczne i traktuje jako identyfikator określonej grupy społecznej (Petrenko 1978, 18; Klochko 2007, 37-38). $\mathrm{Na}$ terenie stepu pojawiają się one dopiero w IV w. p.n.e. (Klochko 2007, 37).

Interesującym, a zarazem problematycznym $\mathrm{w}$ interpretacji kulturowo-chronologicznej okazem jest szpila o główce zakończonej rożkowatymi występami 
(ryc. 1:7). Nie ma dla niej analogii w dotychczas opublikowanych materiałach z ziem polskich, odpowiedników brak też w kontekście ozdób wczesnej kultury scytyjskiej. Najbardziej zbliżona do analizowanego zabytku jest szpila, która pochodzi z wykopalisk przeprowadzonych przez V.V. Chwojkę w miejscowości Visenki w 1899 roku (Petrov 1959, ryc. 7:6). Niestety, zabytek ten nie został znaleziony w kontekście zezwalającym na jakiekolwiek wnioski natury chronologicznej. Jednocześnie pewne szczegóły zajmującego nas okazu obecne są również wśród odległych terytorialnie szpil kultury kobańskiej. Uwagę zwraca przede wszystkim kształt główki tych szpil, aczkolwiek brak charakterystycznych aplikacji zoomorficznych znacząco osłabia ten związek. Tak więc, na obecnym etapie badań kwestia datowania szpili z Chotyńca, stan. 1 pozostaje nierozstrzygnięta.

W konkluzji do zaprezentowanych wyżej obserwacji należy stwierdzić, że szpile znalezione w obrębie zolnika z grodziska w Chotyńcu, stan. 1 mają analogie głównie w jednostkach kulturowych rozwijających się na terytorium ukraińskiego lasostepu w okresie obejmującym koniec VII i początek VI w. p.n.e. Większość zarejestrowanych tu form należy zatem łączyć z etapem zapoczątkowującym rozwój kultury scytyjskiej, tj. z okresem wczesnoscytyjskim, datowanym na VII i 1. połowę VI w. p.n.e. Trzeba jednak zaznaczyć, że datowanie niektórych szpil sięga w głąb VI w. p.n.e. Uwaga ta dotyczy egzemplarzy typu I/1 oraz I/5, które to formy V.G. Petrenko uznała za okazy upowszechniające się dopiero od VI w. p.n.e. Podając tę informację, nie można również pominąć obecności pojedynczych przedmiotów, które na podstawie analogii umiejscowiono w szerokim zakresie datowania (np. VI-III w. p.n.e. - ryc. 2:9) oraz egzemplarzy znacznie młodszych (IV w. p.n.e. - ryc. 2:4). Co prawda, pozycja typologiczno-chronologiczna większości z nich nie wyklucza możliwości synchronizacji badanego zbioru z inicjalnym etapem rozwoju kultury scytyjskiej - nawet w przypadku szerokiego zakresu datowania zawiera się jego dolna data, tj. 1. połowa VI w. p.n.e., jednak ich obecność nakazuje przesunąć datowanie na nieco późniejszy okres i stawia pod znakiem zapytania zwartość całego zbioru. Stwierdzenie to wspierają fakty radiowęglowe (Czopek, Krąpiec 2020). Biorąc to wszystko pod uwagę, należy przesunąć górną granicę ram chronologicznych zbioru co najmniej w głąb VI w. p.n.e., a być może jeszcze później (wiek IV?).

Otwarte pozostaje pytanie o dolną granicę ram chronologicznych badanego zbioru. Pewną wska- zówką w tej kwestii może być szpila o najbardziej „archaicznej” formie, a mianowicie egzemplarz typu I/2 (ryc. 1:2). Jak wcześniej wspomniano, podobne znaleziska można datować na okres od końca VIII do 1. połowy VII w. p.n.e. Istotne jest, że taka pozycja typologiczno-chronologiczna szpili, mimo iż oszacowana wyłącznie na podstawie analogii, znajduje potwierdzenie w datowaniu innych zabytków pozyskanych w trakcie eksploracji zolnika. Kontekstem są tu np. grociki, z których najstarszy reprezentuje formę o romboidalnym, asymetrycznym ostrzu typ Endzhe-Zhabotin (Burghardt 2020). Zdaniem S.V. Polìna $(1987,22)$ grociki tego typu wychodzą $\mathrm{z}$ użycia w połowie VII w. p.n.e. Tak więc analizowany zbiór nie powinien być starszy niż połowa (koniec) VII w. p.n.e.

\section{ANALIZA PLANIGRAFICZNA SZPIL W OBRĘBIE ZOLNIKA - PRÓBA OKREŚLENIA HOMOGENICZNOŚCI ZBIORU}

Jak już wyżej stwierdzono na podstawie analizy typologiczno-porównawczej, zbiór szpil odkrytych w trakcie trzech sezonów badań na zolniku w grodzisku w Chotyńcu wydaje się być niehomogeniczny. Spróbujemy obecnie zweryfikować te ustalenia, tym razem badając szpile przy pomocy nieco innych narzędzi analitycznych. Interesujące wyniki może przynieść np. analiza ich pozycji stratygraficznej w strukturze zolnika. Zakładając, że omawiane zabytki w rzeczywistości są różnoczasowe, należy oczekiwać, że poszczególne ich typy i odmiany wykażą określone tendencje i prawidłowości w rozmieszczeniu. Zanim jednak do tego przystąpimy, odnotujmy kilka istotnych ograniczeń.

$\mathrm{Na}$ podstawie obserwacji przeprowadzonych $\mathrm{w}$ terenie stwierdzono, że zolnik użytkowany był w ramach co najmniej dwóch faz (por. Czopek 2019, 124). Właściwą ocenę relacji chronologicznych zachodzących pomiędzy wyróżnionymi w jego strukturze układami utrudnia jednak destrukcja szczytowych partii obiektu spowodowana działalnością agrotechniczną. $Z$ tej przyczyny trudno określić górną granicę funkcjonowania kompleksu. Stan ten nie wpłynął też korzystnie na ilość materiałów, które można wykorzystać do analiz. Większość interesujących nas źródeł znaleziona została w obrębie tzw. warstwy zolnikowej I, wyższy poziom nie dostarczył porównywalnej puli materiału zabytkowego (ibidem, 133). Należy też 
pamiętać, że poszczególne wydzielone warstwy zalegają in situ tylko w centralnej części kompleksu, stąd niektóre ze szpil mogą pochodzić z części rozsypiskowej (spływowej). Koniecznie uwypuklić należy również inną istotną kwestię. Znaczna część omawianych zabytków reprezentuje typy o dużej rozpiętości czasowej, które w większości nie wychodzą poza ramy okresu wczesnoscytyjskiego (VII - początek VI w. p.n.e.). Sprawia to duże problemy przy próbach rozróżnienia chronologicznego szpil na okazy potencjalnie „młodsze” i potencjalnie „starsze”. Prezentowane $\mathrm{w}$ tej części pracy wnioski należy więc traktować ostrożnie, mając na uwadze wskazane ograniczenia.

Weryfikację poczynionych do tej pory ustaleń chronologicznych rozpoczniemy od obserwacji planigraficznych w obrębie niższego poziomu użytkowego zolnika (ryc. 3; 4). Znalezione tu szpile, choć nieliczne, dostarczają nam kilku istotnych wskazówek. Podkreślenia wymagają przede wszystkim różnice między zawartością analizowanego poziomu a warstwą zalegającą bezpośrednio nad nim. Szpile znane z omawianego kontekstu stratygraficznego to $\mathrm{m}$.in. okazy z charakterystycznym pogrubieniem trzonka typu I/2 (ryc. 1:2) i I/3 (ryc. 1:3, 5, 9). Ozdób z tą cechą szczególną nie udokumentowano na wyższym poziomie zolnika. Obserwacja ta może mieć aspekt chronologiczny, bowiem wymienione typy uznać można za jedne $\mathrm{z}$ najstarszych $\mathrm{w}$ naszym zbiorze. Na podstawie zaprezentowanych analogii datowanie tych odmian ocenić można na przedział czasu od końca VII - początku VI w. p.n.e. W przypadku szpili typu I/2 zasugerować można nawet nieco starszą pozycję chronologiczną. Poza wyżej scharakteryzowanymi na analizowanym poziomie reprezentowana jest także szpila o główce w formie pojedynczej płaskiej tarczki ślimacznicowatej (ryc. $2: 3 ; 3 ; 4$ ). Dla zabytku tego można zasugerować podobne datowanie. Pozycja typologiczno-chronologiczna pozostałych szpil znalezionych na tym poziomie w zasadzie uzupełnia i precyzuje powyższe obserwacje. Po sprawdzeniu, jakie zabytki grupują się w najbliższym sąsiedztwie, okazało się, że są to szpile o wypukłej grzybkowatej główce i łukowatej szyjce, która została osadzona na prostym trzonku, posiadającym zdobienie w postaci spirali złożonej z kilkunastu zwojów (ryc. 1:8, 11). Ich potencjalny czas funkcjonowania sprowadza się do przedziału obejmującego ostatnią ćwierć (koniec) VII i cały VI w. p.n.e. Datowanie to, jakkolwiek niejednoznaczne, nie zaprzecza zatem homogeniczności zbioru, gdyż w jego ramach mieści się w całości zakres chro- nologiczny pozostałych inwentarzy (omówionych wyżej). Warto też odnotować, że z analizowanej części nawarstwień pochodzi problematyczny w interpretacji chronologicznej zabytek, a mianowicie szpila o główce z rożkowatymi występami (ryc. 1:7).

Ogólnie rzecz biorąc, wszystkie szpile znalezione na tym poziomie użytkowym zolnika mieszczą się w przedziale czasu od końca VII w. p.n.e. - VI w. p.n.e., a więc odpowiadają okresowi wczesnej kultury scytyjskiej. Jak na razie nie dysponujemy wieloma danymi zezwalającymi na sprecyzowanie (zawężenie) tego datowania, ale warto uwypuklić kilka przesłanek mogących mieć znaczenie w tej kwestii. Kluczowy może być np. fakt znalezienia w obrębie analizowanego poziomu nawarstwień szpili typu I/2 datowanej na podstawie cytowanych przykładów analogii na połowę VII w. p.n.e. Jak się okazuje, nie jest to jedyny zabytek o tak wczesnej chronologii, jaki udokumentowano w tej części zolnika. Uwagę zwraca przede wszystkim grocik typu Endzhe-Zhabotin (Burghardt 2020), będący najbardziej archaiczną z form w zbiorze grocików chotynieckich (ryc. 3A; 4). Jego chronologię określono na 2. ćwierć VII w. p.n.e. Wielce znaczące w tym kontekście są również znaleziska fragmentów amfor, a zwłaszcza ujawniony w centralnej partii obiektu egzemplarz zachowany w całości (Czopek 2019, ryc. 8). Sugerując się analogiami i biorąc pod uwagę charakter tego znaleziska, można dokładnie wydatować kontekst, z którego pochodzi. Wiadomo bowiem, że pojemniki takie wraz $\mathrm{z}$ winem importowano na cele związane ze sferą rytualną, oraz że najczęściej deponowano je w grobach w niedługim czasie po ich sprowadzeniu. Nasz okaz należy do wyrobów ośrodka w Klazomenei, które produkowano w okresie od końca VII do pierwszych dziesięcioleci VI w. p.n.e. (Sezgin 2004, 173-175). Taka pozycja chronologiczno-typologiczna zabytku koresponduje $z$ datowaniem opisanych wcześniej artefaktów zalegających w bezpośrednim sąsiedztwie. Istotną obserwacją jest też i ta, że na analizowanym poziomie użytkowym zolnika nie odnotowano obecności zabytków młodszych specyficznych wyłącznie dla VI w. p.n.e., a jak wiadomo takie przedmioty pojawiają się w naszym zbiorze. Mając na uwadze analogie i dużą zwartość inwentarzy pozyskanych z omawianego poziomu użytkowego, można przyjąć tezę o ich względnej jednoczasowości, a omawiany poziom użytkowy datować orientacyjnie na koniec VII w. p.n.e.

Możliwości prowadzenia podobnych obserwacji na wyższych poziomach zolnika nie są duże. Głę- 


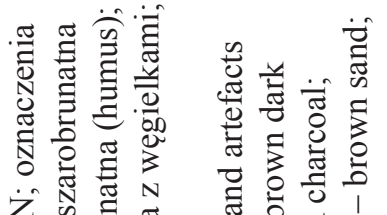
诂 등

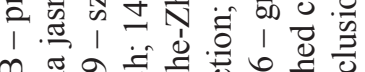

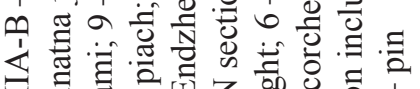

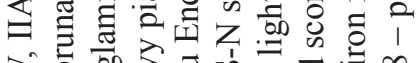

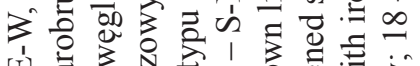

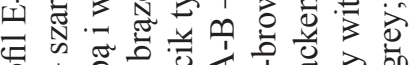

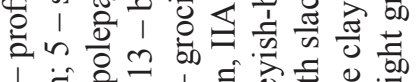

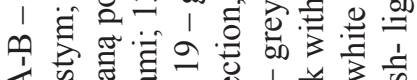

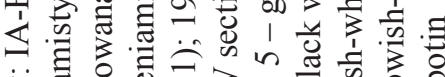

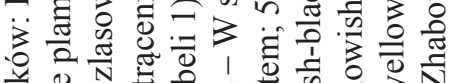

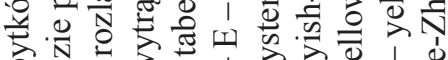
通要

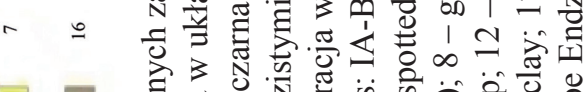

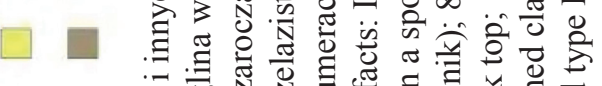
○

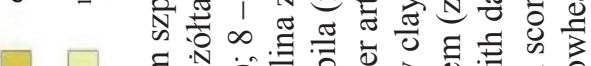

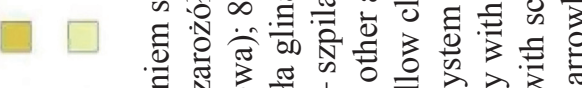

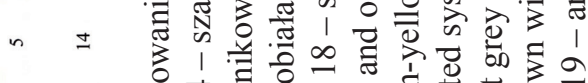

- -

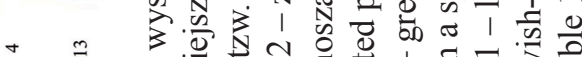

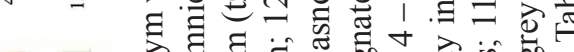

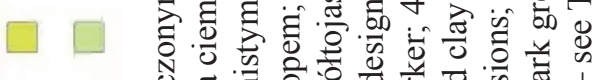

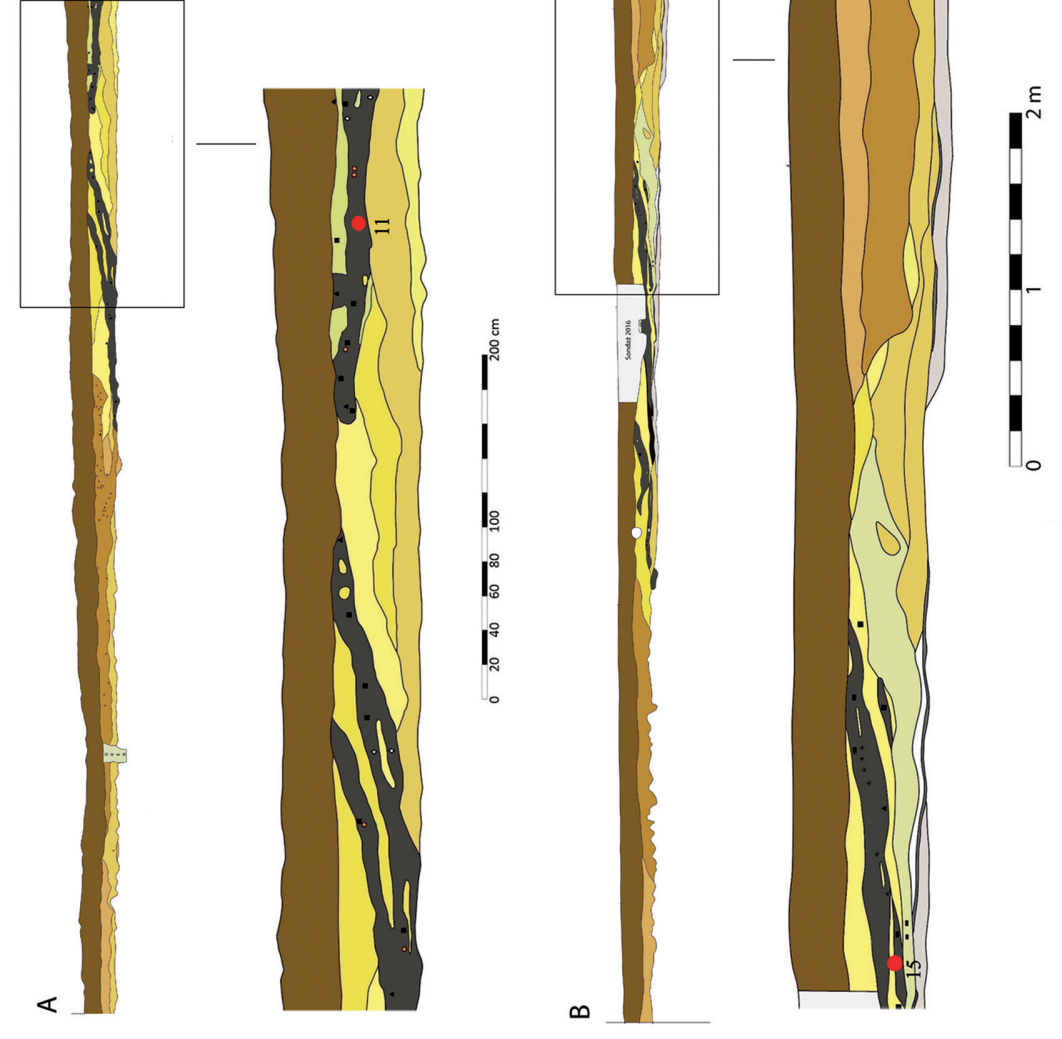

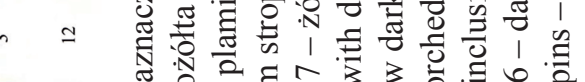

N N. एक

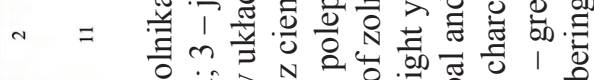

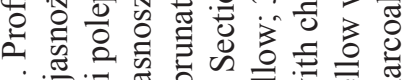

密

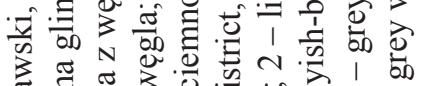

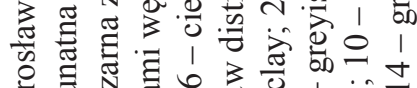

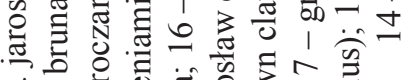

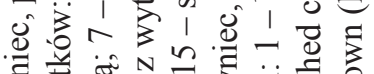

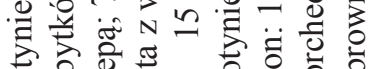
U.

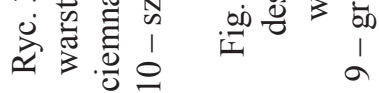

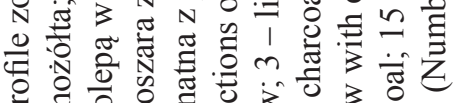

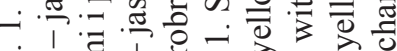

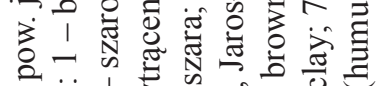

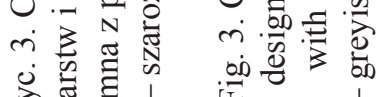




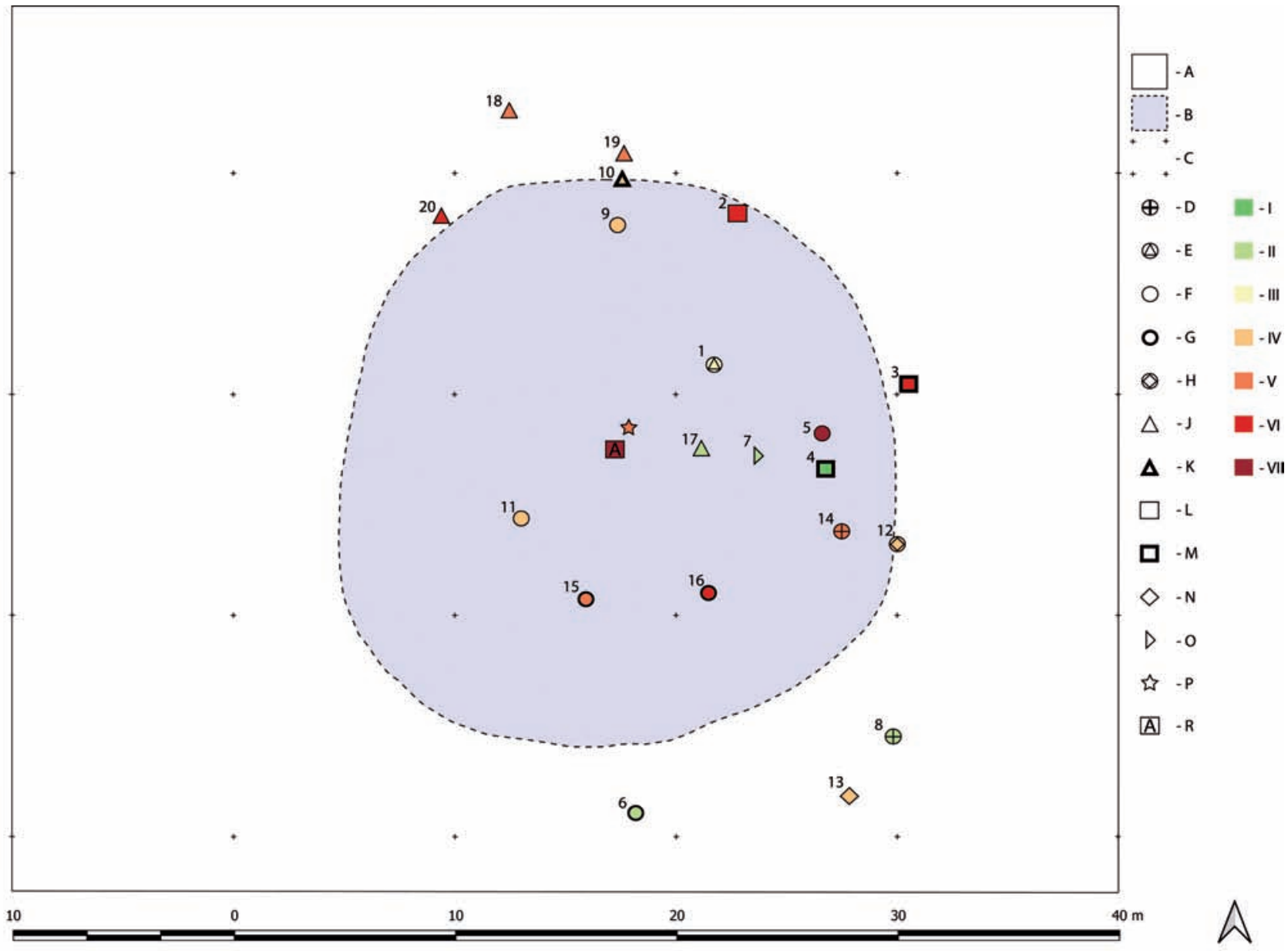

Ryc. 4. Chotyniec, pow. jarosławski, stan. 1. Planigrafia szpil w obrębie zolnika (numeracja wg tabeli 1). Wykaz skrótów: A - obszar rozpoznany wykopaliskowo; B - maksymalny zasięg zolnika; C - siatka arowa; D-H, J-O - typy szpil (D - typ I/1; E - typ I/2; F - typ I/3; G - typ I/4; H - typ I/5; J - typ II/1; K - typ II/2; L - typ III/1; M - typ III/2; $\mathrm{N}$ - typ IV/1; O - typ V/1); P - grocik typu Endzhe-Zhabotin; R - amfora; I-VII - poziom eksploracyjny (I - 25-35 cm; II - 30-40 cm; III - 35-45 cm; IV - 40-50 cm; V - 50-60 cm; VI - 60-70 cm; VII - 65-75 cm)

Fig. 4. Chotyniec, Jarosław district, site 1. Pins planography within the zolnik and its surroundings (Numbering of pins - see Table 1). The lists of abbreviations: A - excavated area; B - maximum range of the zolnik; C - grid; D-H, $\mathrm{J}-\mathrm{O}$ - pins types (D- type I/1; E - type I/2; F - type I/3; G - type I/4; H - type I/5; J - type II/1; K - type II/2;

L - type III/1; M - type III/2; N - type IV/1; O - type V/1); P - arrowhead type Endzhe-Zhabotin; R - Greek amphor; I-VII - exploration level (I - 25-35 cm; II - 30-40 cm; III - 35-45 cm; IV - 40-50 cm; V - 50-60 cm; VI - 60-70 cm; VII - 65-75 cm).

boka orka, jakiej podlegał obiekt przez niemal całą 2. połowę XX wieku, doprowadziła do destrukcji jego pierwotnej powierzchni. Z całą pewnością możemy mówić o jeszcze jednym poziomie użytkowym obiektu, aczkolwiek zachowanym tylko szczątkowo (ryc. 3). Interpretacji chronologicznej nie ułatwia znaczna ilość materiału ruchomego, jaki występuje wokół niego, niekiedy w znacznej odległości (ryc. 4). Możliwe, że zabytki te znalazły się tam w skutek przemieszczenia spowodowanego działalnością agrotechniczną, ale nie można wykluczyć innych wariantów interpretacyjnych (,zguby” w trakcie użytkowania zolnika). Interesujące jest to, że wśród szpil skupiają- cych się na obrzeżach zolnika występują typy o potencjalnie młodszym datowaniu. Należy wśród nich wymienić przede wszystkim żelazne okazy o główkach rozklepanych i zwiniętych w uszko. Na cztery ozdoby o takiej klasyfikacji typologicznej, aż trzy znalezione zostały poza granicami analizowanego obiektu (ryc. $2: 6-8 ; 4)$, natomiast tylko jeden zalegał w jego centrum (ryc. $2: 5 ; 3 \mathrm{~B}$ ). Ostatni z wymienionych przypadków znaleziony został stosunkowo płytko, tuż pod spągiem warstwy współczesnej orki (ryc. 4).

Kolejnym elementem, który zarejestrowano w tej części stanowiska, jest szpila o główce w postaci faliście wygiętego pręta (ryc. 2:4; 4). Przypomnijmy, że 


\begin{tabular}{|c|c|c|c|c|c|c|c|c|c|c|c|c|c|c|}
\hline 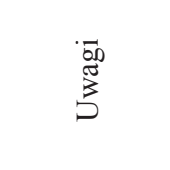 & 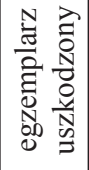 & 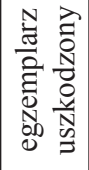 & 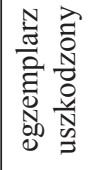 & & 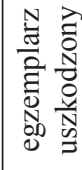 & & & 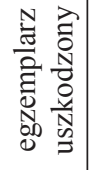 & & 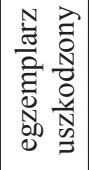 & & & 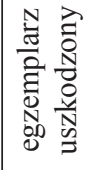 & \\
\hline 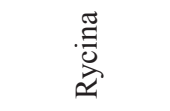 & $\stackrel{\Perp}{-}$ & 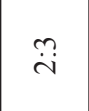 & $\stackrel{\sim}{\sim}$ & $\bar{i}$ & $\stackrel{9}{-}$ & $\stackrel{\circ}{\ddot{-}}$ & $\stackrel{\curvearrowright}{-}$ & $\stackrel{\varphi}{-}$ & $\stackrel{n}{-}$ & $\stackrel{\leftrightarrow}{\dot{i}}$ & $\stackrel{?}{-}$ & 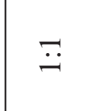 & $\stackrel{+}{i}$ & 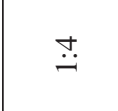 \\
\hline 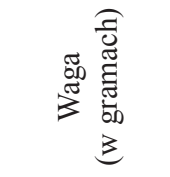 & $\hat{i}$ & $\sigma^{0}$ & $\stackrel{\sim}{i}$ & $\begin{array}{l}\sim \\
\sim\end{array}$ & $\hat{n}$ & $\stackrel{\infty}{\infty}$ & $\stackrel{\forall}{\underset{\leftarrow}{*}}$ & $\overrightarrow{~ ल े}$ & $\stackrel{m}{\sim}$ & $\hat{\circ}$ & $\hat{n}$ & $\stackrel{\sim}{\sim}$ & $\stackrel{\infty}{-}$ & $\hat{m}$ \\
\hline 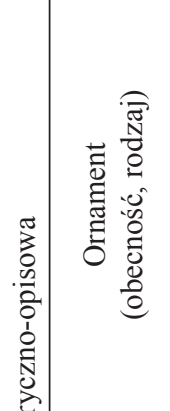 & 苞 & قु & 苟 & 苞 & 弟 & 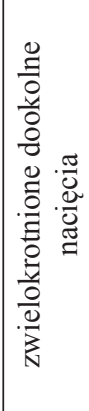 & 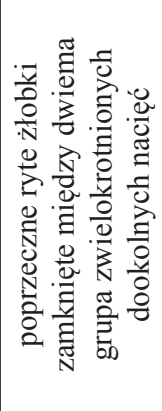 & 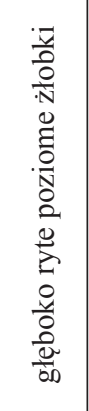 & 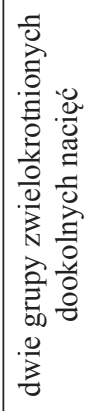 & 苞 & 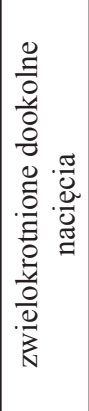 & قु & 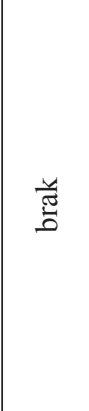 & 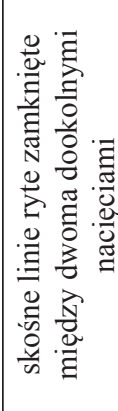 \\
\hline 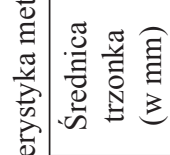 & $\begin{array}{l}\text { * } \\
\text { 声 } \\
\text { 寸 }\end{array}$ & 吉 & $\underset{m}{\Xi}$ & 声 & $\stackrel{*}{*}$ & $\underset{m}{\Xi}$ & $\underset{n}{\Xi}$ & 音 & 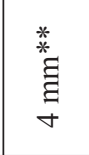 & $\underset{\sim}{\text { 塄 }}$ & 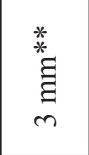 & $\underset{m}{\Xi}$ & $\underset{m}{\Xi}$ & $\underset{\Xi}{\Xi}$ \\
\hline 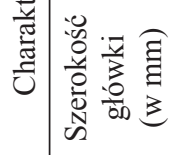 & 当 & 声 & , & 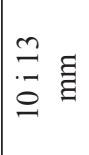 & 当 & $\underset{\infty}{\Xi}$ & 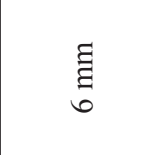 & 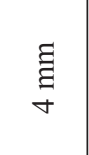 & 节 & $\underset{\infty}{\text { 貝 }}$ & 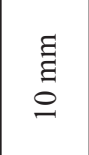 & 声 & 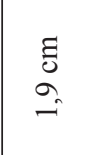 & $\underset{\infty}{\Xi}$ \\
\hline 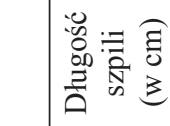 & $\begin{array}{l}\stackrel{*}{\sim} \\
\stackrel{\sim}{*}\end{array}$ & $\begin{array}{l}* \\
n \\
n\end{array}$ & $\stackrel{*}{\varrho}$ & $\simeq$ & $\stackrel{*}{\stackrel{*}{\sim}}$ & $a$ & $\stackrel{\sim}{ \pm}$ & $\stackrel{*_{+}^{*}}{\underset{f}{*}}$ & $a$ & $\stackrel{*}{\sim}$ & $\vec{\Xi}$ & $\stackrel{\simeq}{\simeq}$ & 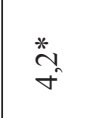 & $\hat{\sigma}_{0}^{2}$ \\
\hline 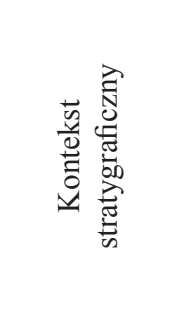 & 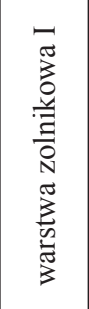 & 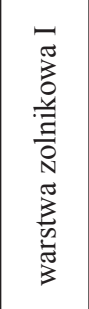 & 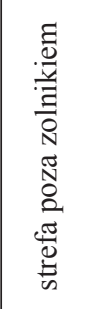 & 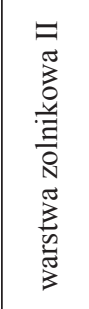 & 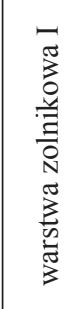 & 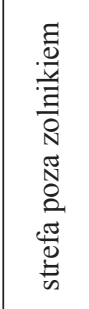 & 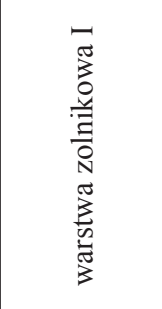 & 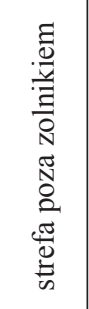 & 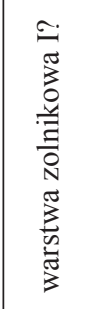 & 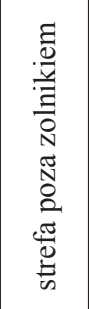 & 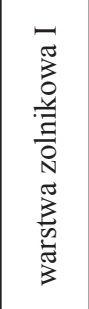 & 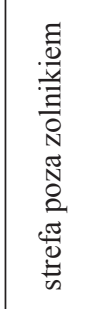 & 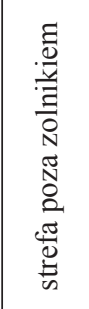 & 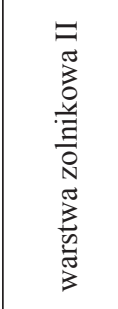 \\
\hline 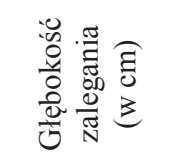 & 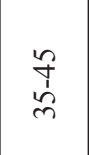 & $\begin{array}{l}\text { P } \\
\text { d }\end{array}$ & $\begin{array}{l}\text { P } \\
\text { d }\end{array}$ & $\begin{array}{l}\tilde{n} \\
\text { ஸे }\end{array}$ & $\begin{array}{l}n \\
\hat{1} \\
0\end{array}$ & 守 & $\begin{array}{l}\text { ơ } \\
\text { d } \\
\text { d }\end{array}$ & $\begin{array}{l}\text { ơ } \\
\text { d } \\
\text { d }\end{array}$ & $\begin{array}{l}\text { o } \\
\text { ó }\end{array}$ & $\begin{array}{l}\stackrel{2}{2} \\
\stackrel{1}{a}\end{array}$ & $\begin{array}{l}\stackrel{2}{2} \\
\stackrel{1}{a}\end{array}$ & 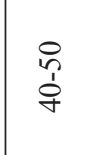 & $\begin{array}{l}\stackrel{0}{1} \\
\stackrel{1}{a}\end{array}$ & $\begin{array}{l}n \\
\tilde{1} \\
\tilde{n}^{2}\end{array}$ \\
\hline 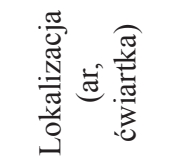 & 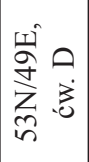 & 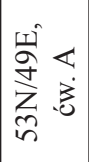 & 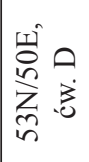 & 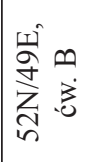 & 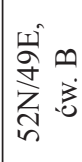 & 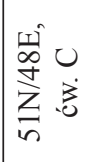 & 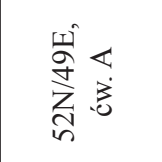 & 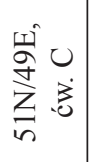 & 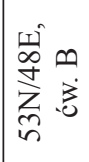 & 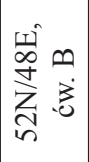 & 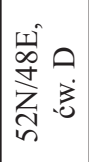 & 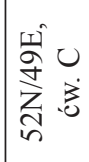 & 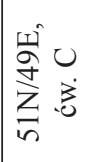 & 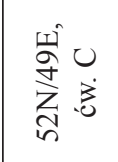 \\
\hline$\stackrel{乛}{\approx}$ & $\stackrel{N}{S}$ & $\vec{\Xi}$ & 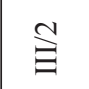 & $\stackrel{\stackrel{\Xi}{\Xi}}{ }$ & $\stackrel{\pi}{\stackrel{\Omega}{\Omega}}$ & $\mathbf{I}$ & $\overrightarrow{>}$ & $\stackrel{\Xi}{\Xi}$ & $\stackrel{0}{s}$ & $\stackrel{N}{\Xi}$ & $\stackrel{0}{\stackrel{2}{\Omega}}$ & $\stackrel{n}{=}$ & $\vec{z}$ & 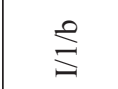 \\
\hline 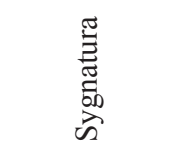 & $\begin{array}{l}\text { ఫे } \\
\text { Ф̆ }\end{array}$ & $\begin{array}{l}m \\
0 \\
\dot{0}\end{array}$ & $\begin{array}{l}\stackrel{ \pm}{0} \\
\dot{0} \\
\dot{0}\end{array}$ & 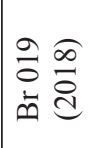 & 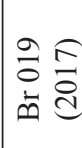 & $\begin{array}{l}n \\
\tilde{0} \\
\dot{n}\end{array}$ & $\begin{array}{l}0 \\
0 \\
\dot{n} \\
\dot{n}\end{array}$ & $\begin{array}{l}\hat{\delta} \\
\hat{0} \\
\bar{n}\end{array}$ & $\begin{array}{l}\tilde{8} \\
\ddot{\infty} \\
\ddot{n}\end{array}$ & 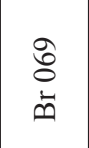 & $\begin{array}{l}\stackrel{\tilde{O}}{0} \\
\dot{\oplus}\end{array}$ & $\begin{array}{l}\ddot{0} \\
\ddot{\infty} \\
\ddot{\infty}\end{array}$ & $\begin{array}{l}\hat{\infty} \\
\stackrel{\circ}{\mathscr{\infty}} \\
\overline{\mathscr{n}}\end{array}$ & $\begin{array}{l}\vec{F} \\
\overrightarrow{0}\end{array}$ \\
\hline$\dot{\imath}$ & $\dashv$ & N & $m$ & $\nabla$ & in & 0 & $\wedge$ & $\infty$ & $a$ & $\circ$ & $\exists$ & $\simeq$ & $\underline{m}$ & $\underset{J}{ \pm}$ \\
\hline
\end{tabular}




\begin{tabular}{|c|c|c|c|c|c|}
\hline 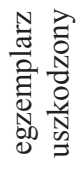 & & & 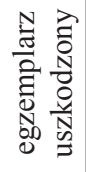 & 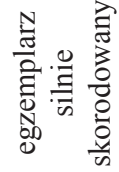 & 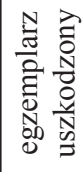 \\
\hline$\underset{ت}{ت}$ & $\stackrel{\infty}{-}$ & 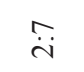 & $\stackrel{\sim}{\sim}$ & $\stackrel{\infty}{\dot{\sim}}$ & $\stackrel{\varphi}{\dot{\sim}}$ \\
\hline 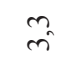 & $\vec{\nabla}$ & $\hat{\sigma}$ & $\begin{array}{l}0 \\
i n\end{array}$ & $\stackrel{n}{m}$ & $\stackrel{0}{m}$ \\
\hline 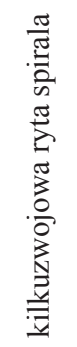 & 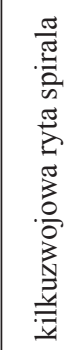 & 苞 & 苛 & 苟 & 崖 \\
\hline$\underset{\text { 国 }}{E}$ & $\underset{m}{\Xi}$ & $\underset{m}{\Xi}$ & 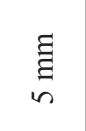 & 声 & $\begin{array}{l}\Xi \\
\vdots \\
n \\
\dot{y}\end{array}$ \\
\hline $\begin{array}{l}\Xi \\
\Xi \\
0\end{array}$ & 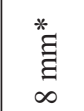 & $\underset{\infty}{\Xi}$ & $\begin{array}{l}\Xi \\
\Xi \\
\stackrel{\Xi}{\Xi}\end{array}$ & $\begin{array}{l}\text { छ్ } \\
\text { ă }\end{array}$ & ' \\
\hline$\underbrace{*}_{0}$ & $\stackrel{*}{*}$ & $\vec{\sim}$ & $\frac{*}{0}$ & $\stackrel{*}{\text { ஸे }}$ & 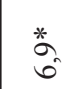 \\
\hline 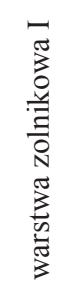 & 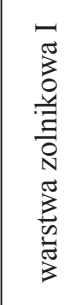 & 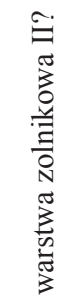 & 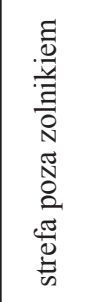 & 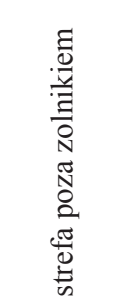 & 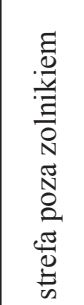 \\
\hline $\begin{array}{l}8 \\
8 \\
1 \\
n \\
n\end{array}$ & $\frac{P}{1}$ & 古 & $\begin{array}{l}8 \\
0 \\
1 \\
i\end{array}$ & $\begin{array}{l}8 \\
i \\
1 \\
i n\end{array}$ & $\begin{array}{l}\stackrel{P}{1} \\
\text { d }\end{array}$ \\
\hline 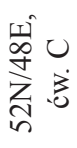 & 敲早 & 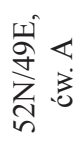 & 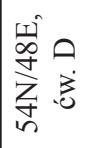 & 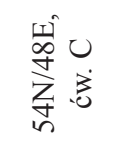 & 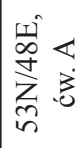 \\
\hline$\stackrel{ \pm}{\Delta}$ & $\stackrel{ \pm}{\Xi}$ & $\Xi$ & $\Xi$ & $\Xi$ & $\Xi$ \\
\hline $\begin{array}{l}\stackrel{\sim}{\Xi} \\
\vec{\oplus}\end{array}$ & $\begin{array}{l}\cong \\
\triangleq \\
\ddot{\bar{n}}\end{array}$ & $\begin{array}{l}\frac{\infty}{0} \\
\frac{\pi}{0} \\
\sum\end{array}$ & 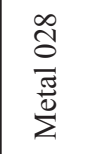 & $\begin{array}{l}0 \\
0 \\
\frac{\pi}{\pi} \\
\sum^{\frac{\pi}{2}}\end{array}$ & $\begin{array}{l}\text { ले } \\
\frac{\pi}{0} \\
\sum^{0}\end{array}$ \\
\hline 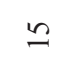 & $\stackrel{0}{-}$ & $\approx$ & 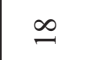 & 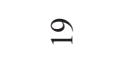 & ㄱ \\
\hline
\end{tabular}

jest to zabytek wyjątkowy o ograniczonych ramach czasowych (IV w. p.n.e.). Z punktu widzenie chronologii ważna jest również obecność typu o zapętlonej główce (II/2 - ryc. 2:9), którego czas trwania na obszarze lasostepu osadzony został w przedziale VI-III w. p.n.e., a w strefie stepu w granicach IV-III w. p.n.e. Pewne odrębności w dystrybucji przestrzennej wykazują też niektóre odmiany szpil gwoździowatych. $\mathrm{Na}$ obrzeżach zolnika (por. ryc. 4) znaleziono formy o płaskiej główce, łukowatej szyjce i ornamentowanej nóżce, które pojawiają się dopiero od VI w. p.n.e. (ryc. 1:1, 6). Analizowana strefa grupuje też zabytki znane z poprzedniego poziomu nawarstwień (ryc. $1: 10 ; 2: 2)$, przy czym sa one nieliczne i reprezentują typy o szerokim zakresie datowania (koniec VII i VI w. p.n.e.).

Powyższe informacje wskazują, że na obrzeżeniach zolnika grupują się zabytki o potencjalnie młodszej pozycji chronologicznej. Trudniej określić datowanie poziomu, który na podstawie układu warstw spalenizny uznany został za młodszy. W związku z tym, że liczba artefaktów zalegających w jego reliktach jest niewielka, relacje chronologiczne między roboczo wydzielonymi poziomami użytkowymi muszą pozostać nierozstrzygnięte. W kontekście tej szczątkowo zachowanej warstwy znaleziono szpilę typu I/1 (ryc. 1:4), dla której formalnym odpowiednikiem jest okaz pochodzący z VI-wiecznej ziemianki z grodziska Bilskiego. Tą samą klasyfikację typologicznochronologiczną posiada też kilka szpil znalezionych poza granicami omawianego kompleksu (por. ryc. 4). Obserwacje te sugerują, że bardziej prawdopodobna jest młodsza pozycja chronologiczna analizowanego poziomu nawarstwień. Należy też zwrócić uwagę, że wśród szpil z warstwy „młodszej”, jak i ze strefy poza pierwotnym zasięgiem zolnika brak jest okazów, które reprezentują najstarsze typy na stanowisku.

\section{PODSUMOWANIE}

Konkludując, należy stwierdzić, że seria szpil pochodzących z zolnika $\mathrm{z}$ grodziska w Chotyńcu jest zbiorem niehomogenicznym. Jak wynika z zaprezentowanych wyżej wniosków natury typologiczno-porównawczej poszczególne zabytki w tej grupie mają różnorodną pozycję chronologiczną, zaś wyselekcjonowanie najstarszych i najmłodszych okazów pozwala umiejscowić analizowany zestaw w szerokim zakresie datowania od końca VII do IV w. p.n.e. $\mathrm{Z}$ punktu widzenia systematyk formalnych rozwoju 
kultury scytyjskiej datowanie analizowanego zbioru zawiera się w przedziale od 3. okresu „Scytii archaicznej" (Aleksejew 2003, 27-29) lub końcowego etapu wczesnej kultury scytyjskiej (ESC-3 - Medvedskaja 1992, 90-93) do późnej fazy okresu scytyjskiego (Aleksejew 2003, tabela 1). Wypada jednak zwrócić uwagę na pewne kontradykcje wynikające $\mathrm{z}$ analizy chronologicznej i podkreślić, że kwestia datowania zolnika wymaga dalszych studiów pod kątem datowania pozostałych zabytków zdeponowanych na poszczególnych poziomach jego nawarstwień.

Z przeglądu analogii wynika, że zdecydowana większość szpil znalezionych na grodzisku w Chotyńcu to formy przewodnie dla okresu wczesnoscytyjskiego. $\mathrm{Z}$ tym stosunkowo bogatym zbiorem zabytków wyraźnie kontraktuje ubóstwo materiałów z okresów młodszych. Reprezentuje je w zasadzie jedna szpila datowana na IV w. p.n.e. (ryc. 2:4) i kilka zabytków o szerokich ramach czasowych, które jednak częściowo zahaczają o wskazany etap rozwoju kultury scytyjskiej. W kontekście zniszczenia i rozorania górnych poziomów użytkowania zolnika jest to częściowo zrozumiałe. $Z$ drugiej jednak strony nie można wykluczyć błędnej identyfikacji typologicznej tych szpil. Nie negując powyższych wątpliwości, warto dodać, że oznaczenia chronometrii radiowęglowej sugerują dłuższe użytkowanie zolnika (Czopek, Krąpiec 2020), tj. przemawiają za poprawnością określeń typologiczno-chronologicznych zabytków i przesunięciem jego górnych ram poza etap utożsamiany z wczesnym okresem kultury scytyjskiej.

Analizy planigraficzne dały możliwość potwierdzenia tezy o dwufazowości analizowanego kompleksu. Mimo pewnych zniszczeń różnice chronologiczne między obserwowanymi w strukturze zolnika poziomami są czytelne. Obraz zarysowany na podstawie wskazówek typologicznych i danych planigraficznych, wskazuje, że czynności kultowo-obrzędowe na zolniku zostały zapoczątkowane w przedziale synchronizowanym $\mathrm{z}$ wczesnym okresem kultury scytyjskiej. Łącząc pozostałe fakty wynikające $\mathrm{z}$ analizy zabytków, które w świetle aktualnego stanu wiedzy są bardziej precyzyjnymi datownikami (np. grociki - por. uwagi Chochorowski 2014, 36-37), okres użytkowania najniższego poziomu można ocenić na koniec VII w. p.n.e.

Pozycja typologiczno-chronologiczna szpil znalezionych na wyższym poziomie użytkowym zolnika oraz egzemplarzy zarejestrowanych poza granicami kompleksu (zolnika) wskazuje, że zdecydowana większość z nich upowszechnia się dopiero w VI w. p.n.e. Brak jest wśród nich cech dystynktywnych dla zabytków potencjalnie najstarszych (z końca VII w. p.n.e.), które rejestrujemy na niższym poziomie nawarstwień. Przesłankę tę można przyjąć za dowód na wielofazowość analizowanego kompleksu. Trudniej jest natomiast wypowiedzieć się na temat zróżnicowania czasowego szpil ze wskazanych stref. Szeroki zakres datowania zabytków zalegających na obrzeżach lub poza granicami może sugerować przemieszanie różnoczasowych elementów. Na obecnym etapie badań nie dysponujemy przesłankami umożliwiającymi wskazanie ilości faz użytkowych, a tym samym określenia górnej granicy funkcjonowania kompleksu. Dość prawdopodobna jest jednak, że chronologia zolnika wykracza poza ramy okresu wczesnoscytyjskiego. Zachowany szczątkowo młodszy poziom użytkowy należy prawdopodobnie datować na VI w. p.n.e., jego pierwszą połowę.

Na zakończenie warto zwrócić uwagę na spory potencjał informacyjny zajmującej nas grupy zabytków. Szpile, powszechnie traktowane jako przedmioty o przeznaczeniu utylitarnym lub symbolicznym, są też swoistymi identyfikatorami określonych grup etnicznych bądź też funkcji społecznej (Klochko 2007, 28). Już sama ich obecność na zolniku prowokuje do pewnych refleksji. Przede wszystkim należy zauważyć, że większość z przytoczonych analogii do okazów serii chotynieckiej pochodzi z terytorium lasostepu. Obserwacja ta pozostaje w zgodzie z wyliczeniami V.G. Petrenko, zdaniem której szpile stanowią kategorię ozdób typową dla tej strefy; poza nią badaczka odnotowała jedynie 3,5\% zabytków tego rodzaju (1978, tabela 1). Dla kontrastu warto też przytoczyć wyniki podobnych analiz dla strefy stepu. S.V. Ol'hovskij $(1991,113)$ w pracy na temat obrządku pogrzebowego ugrupowań tej części Scytii pisze o zaledwie kilku pochówkach, w wyposażeniu których znalezione zostały szpile (5 grobów, co stanowi $0,4 \%$ wszystkich grobów z okresu V - IV-III w. p.n.e.). Biorąc pod uwagę zaprezentowane prawidłowości, należy stwierdzić, że zajmująca nas grupa zabytków jest kolejnym elementem, który przemawia za przynależnością kulturową grodziska w Chotyńcu do leśnostepowego wariantu kultury scytyjskiej.

Kolejną ważną kwestią jaką należy poruszyć, jest związek rzeczonych zabytków z płcią. Patrząc przez pryzmat zespołów grobowych kultury scytyjskiej, można dojść do wniosku, że szpile były atrybutami stroju kobiet. Według zestawienia, jakie opublikowała V.G. Petrenko w 1978 roku, obecność zabytków o zajmującej nas kwalifikacji funkcjonalnej potwier- 
dzono w 42 pochówkach kobiet i tylko 2 zespołach o męskim modelu wyposażenia (tabela 1). Trudno jest wskazać na obecnym etapie badań na aktualne prace poruszające ten problem w odniesieniu do okresu wczesnoscytyjskiego. Kwestia wyznaczników płci $\mathrm{w}$ grobach $\mathrm{z}$ tego etapu nie została jeszcze w pełni usystematyzowana. Wydaje się jednak, że związek szpil z pochówkami kobiet jest niepodważalny. Z etapu zapoczątkowującego rozwój kultury scytyjskiej znamy tylko pojedyncze przypadki zespołów, gdzie szpila została znaleziona $\mathrm{w}$ jednostkowych grobach o męskim charakterze wyposażenia (np. BalikoSchuchinka, kurhan nr 2 - Czernenko 1964, 37-38). W zdecydowanej większości są to pochówki kobiet. Dla przykładu można wymienić m.in. zespoły z następujących miejscowości: Połtawa (pochówek nr 1, kobieta w wieku 16-18 lat-Suprunenko 2016, 97-98), Skorobor (kurhan nr 2/1965, kobieta w średnim wieku - Shramko 1994, 103, 107) i Voloshinoe (grupa kurhanowa $\mathrm{nr}$ 2, kurhan $\mathrm{nr} 1$, kobieta w wieku 25-30 lat - Kulatova et al. 2006, 48-50). Są to pochówki o płci potwierdzonej przez analizy antropologiczne. Szpile, jako element wyposażenia, pojawiają się też w grobach męsko-żeńskich z tego okresu, co prezentują takie zespoły jak: Andrushevka (kurhan 1, pochówek 1
- Voroncov, Skoryj 2012, 138-144) i Karpusy (kurhan nr 1, pochówek nr 7 - Suprunenko et al. 1996, 24-34). Również w okresach późniejszych zabytki te stanowiły element wyposażenia charakterystyczny dla osobników płci żeńskiej. Na wyłączny związek tej kategorii ozdób z kobietami zwrócił uwagę M. Burghardt, analizując wyznaczniki płci w grobach ludności grup leśnostepowych kultury scytyjskiej $(2016,190)$. Podobnego zdania są też inni badacze (Kovpanenko et al. 1989, 73, 101). W kontekście zaprezentowanych danych można by było zaryzykować stwierdzenie, że obecność szpil na zolniku w Chotyńcu, a więc w miejscu, któremu przypisuje się funkcje rytualno-obrzędowe wskazuje na możliwość zaangażowania kobiet w sferę takich praktyk. Co istotne - zabytki o takiej klasyfikacji funkcjonalnej występują też na innych tego typu obiektach. Przykładem mogą tu być np. zolniki z miejscowości Barchany (Shramko, 2003, ryc. 4:28-30) lub Czeremuszna (Liberov, ryc. 10:1-6, 8). Warto też przypomnieć, że obecność szpil w inwentarzach grobowych miejscowych ugrupowań tarnobrzeskich nie jest rzeczą symptomatyczną wyłącznie dla jednej z płci (por. Przybyła 2004, 99; Niemiec 2006, 133; Rajpold 2017, 95n).

\section{BIBLIOGRAFIA}

Abramowa et al. = Абрамова М.П., Бессонова С.С., Дашевская О.Д., Дворниченко В.В., Каменецкий И.С., Козенкова В.И., Кореняко В.А., Крис Х.И., Кузнецова Т.М., Марковин В.И., Мелюкова А.И., Мирошина Т.В., Мошкова М.Г., Петренко В.Г., Смирнов К.Ф. (1989). Степи европейской части СССР в скифо-сарматское ввремя. Москва: Издательство „Наука”.

Aleksejew $=$ Алексеев А.Ю. (2003). Хронография Европейской Скифии VII-IV веков до н.э. СанктПетербург: Издательство Государственного Ермитажа.

Andrienko = Андриенко В.Л. (1996). Булавки с поселения у с. Пожарная Балка. W: О.Б. Супруненко (red.), Більське городище в контексті вивчення пам'яток раннього залізного віку європи (353-358). Полтава.

Bessonowa, Skoryj = Бессонова C.С., Скорый С.А. (2001). Мотронинское городищче скифской эпохи. КиевКракков: Национальная Академия Наук Украины
Институт Археологии, Ягеллонский Университет Институт Археологии.

Blajer W. (2001). Skarby przedmiotów metalowych z epoki brązu i wczesnej epoki żelaza na ziemiach polskich. Kraków: Księgarnia Akademicka.

Burghardt M. (2016). Wyznaczniki płci w grobach ludności grup leśnostepowych kultury scytyjskiej. Materiaty i Sprawozdania Rzeszowskiego Ośrodka Archeologicznego, 37, 165-200.

Burghardt M. (2020). Classification and chronology of the collection of arrowheads from ash-hill found in hillfort of the Scythian Cultural Circle in Chotyniec, site 1, Jarosław district. Sprawozdania Archeologiczne, 72, 327-355.

Chochorowski J. (2014). Scytowie a Europa Środkowa - historyczna interpretacja archeologicznej rzeczywistości. Materiaty i Sprawozdania Rzeszowskiego Ośrodka Archeologicznego, 35, 9-58. 
Cofta-Broniewska A., Hensel Z. (1996). Metalurgia brązu pradziejowych społeczeństw Kujaw. Poznań: Uniwersytet im. Adama Mickiewicza w Poznaniu.

Czopek S. (1992). Zabytki żelazne w materiałach grupy tarnobrzeskiej. W: S. Czopek (red.), Ziemie polskie we wczesnej epoce żelaza $i$ ich powiazania z innymi terenami (111-126). Rzeszów: Muzeum Okręgowe w Rzeszowie.

Czopek S. (1996). Grupa tarnobrzeska nad środkowym Sanem i dolnym Wisłokiem. Rzeszów: Muzeum Okręgowe w Rzeszowie.

Czopek S. (2019). Enklawa scytyjskiego kręgu kulturowego w południowo-wschodniej Polsce. Przegląd Archeologiczny, 67, 119-148. doi: 10.23858/PA67.2019.007.

Czopek S., Krąpiec M. (2020). The cult area (zolnik) from the hillfort of the Scythian cultural circle in Chotyniec near Radymno (south-estern Poland) in the context radiocarbon dating. Radiocarbon, 62, 1599-1611.

Czopek S., Trybała-Zawiślak K., Tokarczyk T., OcadrygaTokarczyk E., Burghardt M, Adamik-Proksa J., Rajpold W. (2017). Pierwsze sprawozdanie z weryfikacyjnych badań na grodzisku z wczesnej epoki żelaza w Chotyńcu. Materiaty i Sprawozdania Rzeszowskiego Ośrodka Archeologicznego, 38, 291-305. doi: 10.15584/misroa.2017.38.15.

Czopek S., Trybała-Zawiślak K., Wojceszczuk N., Osaulczuk O., Bobak D., Gębica P., Jacyszyn A., Pasterkiewicz W., Pawliw D., Petehyrycz W., Połtowicz-Bobak M., Wacnik A. (2018). Przemiany kulturowo-osadnicze $w$ dorzeczu rzeki Wiszni w epoce brazu $i$ we wczesnej epoce żelaza $w$ kontekście zmian prahistorycznej i wczesnohistorycznej ekumeny. Rzeszów: Wydawnictwo Uniwersytetu Rzeszowskiego.

Czernenko = Черненко Е.В. (1964). Скіфські бойові пояси. Археологія, 16, 27-48.

Daragan = Дараган М.Н. (2011). Начало раннего железного века в Днепровской Правобережной Лесоcmenu. Киев: Институт Археологии Национальной Академии Наук Украины.

Dąbrowski J. (2004). Ältere Bronzezeit in Polen. Warszawa: Wydawnictwo Instytutu Archeologii i Etnologii PAN.

Essen R. (1985). Die Nadeln in Polen II (Mittlere Bronzezeit). Prähistorische Bronzefunde, 13 (9).

Gawlik A. (2005). Znaleziska scytyjskie w zasięgu kultury wysockiej. W: S. Czopek, J. Podgórska-Czopek (red.), Problemy kultury wysockiej (205-219). Rzeszów: Muzeum Okręgowe w Rzeszowie.

Gedl M. (1983). Die Nadeln in Polen I (Frühe und ältere Bronzezeit). Prähistorische Bronzefunde, 13 (7), München.
Grechko=Гречко Д.С. (2010). Населення скіфського часу на Сіверському Діниі. Київ: Інституту археології НАН України.

Gucal et al. = Гуцал А.Ф., Гуцал В.А., Мегей В.П., Могилов О.Д. (2003). Результати досліджень курганів скіфского часу біля с. Теклівка на Поділлі. Археологічні відкриття в Україні 2001-2002, 9092.

Gucal et al. = Гуцал А.Ф., Гуцал В.А., Мегей В.П., Могилов О.Д. (2004). Розкопки курганіні в епоху ранньої інвентаризації в Малинівці на Середньому Дністрі. Археологічні відкриття в Україні 20022003, 114-116.

Klochko = Клочко Л.С. (2007). Шпильки у вбранні населення Скіфії. W: Л.В. Строкова, Л.С. Клочко, Ю.О. Білан, С.А. Березова (red.) Музейні читання. Матеріали наукової конферениії „Ювелірне мистецтво-погляд крізь віка”. 11-13 грудня 2006 р. (28-41). Київ.

Klochko = Клочко Л.С. (2016). Декоративні елементи жіночого вбрання на землях Правобережної Скіфії. Археологія і давня історія України, 2(19), 103-113.

Kłosińska E.M. (2010). Nowe znaleziska brązowe ze Starego Machnowa, pow. Tomaszów Lubelski. Archeologia Polski Środkowowschodniej, 10(2008), 237-248.

Kłosińska E.M. (2013). Research problems of the Lusatian culture in the early Iron Age in the Lublin region in the light of new archaeological findings. W: J. Kolenda, A. Mierzwiński, S. Moździoch, L. Żygadło (red.), Z badań nad kultura spoleczeństw pradziejowych $i$ wczesnośredniowiecznych. Księga jubileuszowa dedykowana Profesorowi Bogusławowi Gedidze w osiemdziesiąta rocznice urodzin przez przyjaciót, kolegów i uczniów (424-449). Wrocław: Instytut Archeologii i Etnologii Polskiej Akademii Nauk, Ośrodek Badań nad Kulturą Późnego Antyku i Wczesnego Średniowiecza.

Kostrzewski J. (1953). Ze studiów nad wczesnym okresem żelaznym w Polsce. Slavia Antiqua, 4, 22-70.

Kowalski-Biłokryłyy J. (2012). Chronologia grupy zachodniopodolskiej scytyjskiego kręgu kulturowego. Матеріали і дослідження з археології Прикарпаття і Волині, 16, 160-189.

Kowpanenko = Ковпаненко Г.Т. (1981). Курганы раннескифского времени в бассейне р. Рось. Киев: „Науковаа думка”.

Kowpanenko et al. = Ковпаненко Г.М., Бессонова С.С., Скорый С.А. (1989). Памятники скифской епохи днепровского лесостепного Правобережья. Киев: „Науковаа думка”. 
Kulatova et al. = Кулатова И.Н., Скорый С.А., Супруненко А.Б. (2006). Раннескифское погребение на юге Приднепровской Левобережной террасовой Лесостепи (к вопросу о переднеазиатских инновациях в восточноевропейском зверином стиле). Археологічний літопис Лівобережної України, 1, 46-60.

Kunysz A. (1968). Grodziska w województwie rzeszowskim. Materiaty $i$ Sprawozdania Rzeszowskiego Ośrodka Archeologicznego za rok 1966, 25-87.

Liberov = Либеров П.Д. (1962). Памятники скифского времени бассейна Северского Дониа. Лесостепные культуры скифского времени (= Материалы и исследования по археологии СССР, № 113). Москва: Издательство Академии Наук ССР.

Lifantii O., Shelekhan O. (2018). Metal artefacts from the Severynivka hillfort. Baltic-Pontic Studies, 21, 255276.

Lysenko, Lysenko = Лысенко C.C., Лысенко С.Д. (2019). Булавки с петельчатой головкой эпохи поздней бронзы. Материаль по Археологии Северного Причерноморья, 14, 161-181.

Medwedskaja = Меддведская И.Н. (1992). Периодизация скифскоий архикии Деревний Восток. Российская Археология, 3/1993, 86-107.

Moskwa K. (1976). Kultura tużycka w południowowschodniej Polsce. Rzeszów: Muzeum Okręgowe w Rzeszowie.

Niemiec Ł. (2006). Brązowe i żelazne szpile z główką sklepaną i zwiniętą w uszko w tarnobrzeskiej kulturze łużyckiej. Materiały i Sprawozdania Rzeszowskiego Ośrodka Archeologicznego, 27, 119-176.

Ol'hovskij = Ольховский В.С. (1991). Погребальнопоминальная обрядность населения степной Скифии (VII-III вв. до н. э.). Москва: Наука.

Petrenko = Петренко В.Г. (1978). Украшения Скифии VII-III вв. до н.э. (= Археология СССР, Свод Археологических Источников, в. Д 4-5). Москва: Издательство Наука.

Petrov = Пемров В.П. (1959). Зарубинецкий могильник (По материалам раскопок В. В. Хвойки в 1899 г.). Материалы и исследования по археологии СССР, 70, 32-60.

Polin = Полин С.В. (1987). Полин Хронологія ранньо скіфський пам'яток. Археологія, 59, 17-36.

Przybyła M. (2004). Wybrane aspekty obrządku pogrzebowego grupy tarnobrzeskiej. Materiaty i Sprawozdania Rzeszowskiego Ośrodka Archeologicznego, 25, 91-103.

Rajpold W. (2017). Szpile w tarnobrzeskiej kulturze łużyckiej. Przyczynek do badań nad ich związkiem z wiekiem i płcią oraz rozważania na temat pojawienia się żelaza. Materiaty i Sprawozdania Rzeszowskiego Ośrodka Archeologicznego, 38, 73-100. doi: 10.15584/ misroa.2017.38.5.

Sezgin Yu. 2004. Clazomenian Transport Amphorae of the Seventh and Sixth Centuries. W: A. Mustaka (red.). Klazomenai, Teos and Abdera: Metropoleis and Colony. Proceedings of the International Symposium held at the Archaeological Museum of Abdera. Abdera 2021 Oktober 2001 (169-183). Thessaloniki: Univ. Studio Press.

Shramko = Шрамко Б.А. (1987). Бельское городище скифской эпохи (город Гелон). Киев: Наукова думка.

Shramko = Шрамко Б.А. (1994). Новые раскопки курганов в могильнике Скоробор. Древности, 1, 102-106.

Shramko = Шрамко І.Б. (2003) Исследование округи Люботинского городища. Археологічний літопис Лівобережної України, 2, 102-108.

Shramko = Шрамко І.Б. (2006). Ранній період в історії геродотівського Гелону (за матеріалами розкопок зольника № 5). W: О.Б. Супруненко (red.), Більсье городище та його округа (до 100- річчя початку польових досліджень) (33-56). Киев: Шлях.

Smirnowa = Смирнова Г.И. (1981). Новые данные о поселении в с. Долиняны (по материалам раскопок 1977-1978 гг.). Археологический сборник Государственного Эрмитажа, 22, 40-61.

Smirnowa = Смирнова Г.И. (2004). Состояние изучения Западно-Подольскоий группы памятников раннескифского времени в Лесостепноий Скифии в конце XX века. W: J. Chochorowski (red.), Kimmerowie, Scytowie, Sarmaci. Księga poświęcona pamięci Profesora Tadeusza Sulimirskiego (409-429). Kraków: Uniwersytet Jagielloński Instytut Archeologii.

Sulimirski T. (1936). Scytowie na zachodnim Podolu. Lwów: Lwowskie Towarzystwo Prehistoryczne.

Sulimirski T. (1931). Kultura wysocka. Kraków: Polska Akademia Umiejętności.

Suprunenko = Супруненко О.Б. (2016). Грунтовий могильник Полтавського поселення ранньоскіфськогї доби. W: О.Б. Супруненко (red.), Cmaрожитності Лівобережного Подніпров'я. Збірник наукових праць (94-111). Киев: Центр пам'яткознавства НАН України і Утопік.

Suprunenko et al. = Супруненко О., Золотницький Б., Кулатова I. (1996). Кургани біля с. Карпусі під Полтавою. Полтава: Видавничий центр „Археологія".

Trachsel M. (2004). Untersuchungen zur relativen und absoluten Chronologie der Hallstattzeit. Bonn: Habelt. 
Trybała-Zawiślak K. (2012). Kłyżów, stan. 2 i Mokrzyszów, stan. 2 - cmentarzyska ciałopalne z wczesnej epoki żelaza. Rzeszów: Wydawnictwo Mitel, Instytut Archeologii Uniwersytetu Rzeszowskiego.

Trybała-Zawiślak K. (2019). Wczesna epoka żelaza na terenie Polski poludniowo-wschodniej - dynamika zmian i relacje kulturowe. Rzeszów: Wydawnictwo Uniwersytetu Rzeszowskiego.

Voroncov, Skoryj = Воронцов Д., Скорый С. (2012). Андрушевский Курган. Revista Arheologică, serie nоиӑ, 8(1-2), 137-153.

\title{
JOANNA ADAMIK-PROKSA, EWELINA OCADRYGA-TOKARCZYK
}

\author{
THE PROBLEM OF THE CHRONOLOGY OF THE ZOLNIK FROM \\ THE BURGWALL IN CHOTYNIEC, POLAND AND ITS USAGE LEVELS \\ IN LIGHT OF RESEARCH ON THE CLASSIFICATION AND DATING OF PINS
}

\author{
SUMMARY
}

Despite its short research history, the Chotyniec burgwall is an object well known from archaeological literature. This is due to the specificity of the sources recorded here (Greek amphorae, numerous metal artifacts, including Scythian arrowheads) and the fact that it is the westernmost object of its kind within the reach of Scythian culture. The only place in the area of the fortified settlement that has been studied comprehensively and completely so far is the zolnik. This unique object, to which ritual functions are attributed, was very intensively used. This is evidenced by its complex stratigraphy and the number of artefacts found within it. On the basis of observations made in the field, it was established that this establishment was located on a previously levelled ground. It was based on a mound of yellow clay. The structure of the zolnik was followed by: an intensely black layer of burning, abounding in movable sources - i.e., "zolnik layer I", an uneven layer of yellow clay devoid of any historical objects, and which was a "dividing line" between the levels of burning, and a "zolnik layer II" preserved only on the outskirts of the object, with the same colour and consistency as the lower level. Unfortunately, the ceiling of the latter creation was destroyed by modern agricultural activities.

During the investigations into the zolnik a considerable number of archaeological materials was obtained. These are: handmade ceramics, Greek amphorae and their fragments, spans, beads, military accessories, and numerous decorations - including pins, which are the subject of this article. The number of pins included in the study is 21 (Fig. 1,2). The list is supplemented by destroyed specimens
- wire fragments of various lengths (Fig. 2:12-15) and only partially preserved bones with sharpened ends (Fig. 2:10, 11). Based on the criterion of the shape of the head, several groups can be distinguished in the collection of Chotyniec pins. These are: nail pins (type I - Fig. 1:1-6, 8-11), pins with blunted ends and ones rolled up ends (type II - Fig. 2:5-9), pins with one or two heads in the form of helical disks (type III - Fig. 2:1-3), pins with a head in the form of a (double) wave-shaped bent rod (type IV - Fig. 2:4), and a specimen with a head ending in corrugated protrusions (type V-Fig. 1:7).

The most numerous are type I pins, i.e., specimens with a nail head. They are not a homogeneous group, hence the V.G. Petrenko (1978) classification was used to organize them formally. Based on the division criteria proposed by the researcher (shape of head, neck and shank), the following were distinguished: pins with a flattened head, arched neck, and a straight stem decorated with horizontal incisions (subtype I/1 - Fig. 1:4, 6), a specimen with a slightly arched "mushroom-shaped" head and a conical neck, the edges of which connect to the edge of the head and to the widened stem (subtype I/2 - Fig. 1:2), pins with a convex head, an arched neck and a stem containing an oval extension more than half its height (subtype I/3 - Fig. 1:3, 5, 9), pins with a convex head, arched neck, and a straight shaft decorated with a few girdles (subtype I/4 - Fig. 1:8, 10, 11), and a specimen with a small flat head, arched neck, and an unbroken straight shaft (subtype I/5 - Fig. 1:1).

Type II is made up of pins with the ends unbuttoned and rolled up. The basic features differentiating the arti- 
facts in this group include: material (iron or bronze) and size. By correlating the relations between these parameters two subtypes can be distinguished. The first is made up of iron pins (subtype II/1). The second one represents a miniature bronze specimen with an upper part shaped like an ear, which was created by slightly tapping and twisting one of the ends of the handle into a loop (subtype II/2 - Fig. 2:9).

Type III consists of pins made of brown wire with heads in the form of spiral discs. Taking into account the number of heads assigned to this type, two sub-types can be distinguished: a pin with a head in the form of a single flat helical disc (subtype III/1 - Fig. 2:3) and specimens with two spiral discs (subtype III/2 - Fig. 2:1,2).

Apart from the ornaments characterized above, the group of Chotyniec pins is also represented by types known from single specimens. These are: a pin with a quite specific form, with a head in the form of a double (wavy) bent rod with a riveted end (type IV - Fig. 2:4) and a pin with a split end forming corners, adorned in the upper part of the stem with an extensive combination of transverse and horizontal grooves (type V - Fig. 1:7).

In this article a comparative-typological analysis of the pins was carried out in order to establish their chronological position and thus determine the time frame of the functioning of the complex (zolnik). After analyzing the analogy to the pins of the Chotyniec series, it was established that the ornaments found in the zolnik in Chotyniec correspond mainly to the historical objects known from cultural units developing on the territory of the Ukrainian forest-steppe in the period covering the end of the 7 th and beginning of the 6th century BC. Therefore, most of the forms registered here should be connected with the stage that initiated the development of Scythian culture, i.e., the Early-Scythian period. It should be noted, however, that some pins have ambiguous chronological definitions. This note applies to specimens dating back to the entire 6th century B.C. (Figures 1:1, 4, 6) and forms with a wider dating range (Figures 2:5-9). The chronology of a specimen with a wave-shaped head is also problematic (Fig. 2:4). Due to the design of the head, this pin is classified as type 24 according to V.G. Petrenko (1978) and dated to the 4th century B.C. (Klochko 2007, 37). The above data indicate the heterogeneity of the collection, and the selection of the oldest and youngest artifacts in the group allows us to determine the timeframe for the functioning of the zolnik to be from the end of the 7 th to the 4 th century BC.

The data on the differences in the distribution of pins with the discussed functional qualification are interesting. It turns out that in spite of some damage, the phasing of the use of the zolnik is quite clear. On the basis of typological indications and planning data it is possible to state that the cult and ritual activities in the zolnik were initiated in the range synchronized with the early period of Scythian culture. This statement is supported by the fact that pins were found within the "zolnik layer I", which are the oldest types on the site. This observation applies to the specimen with the most archaic form (Fig. 1:2), which has parallels in the Žabotin III phase (cf. Daragan 2011, Fig. V:1) and the specimens that refer to it in a formal manner (Fig. 1:3, $5,9)$. Such objects were found only at this level of layering. It is also noteworthy that within this layer no younger pins specific only for the 6th century B.C. were registered, and as we know such objects appear in our collection.

Due to the ploughing of the top parts of the complex, the possibilities of assessing the upper limit of its functioning are not great. We can however talk about one more utility level of the object, although it has been preserved only residually (Fig. 3). The chronological interpretation is not facilitated by the considerable amount of moving material around it, sometimes at a considerable distance (Fig. 4). Nonetheless, it is worth noting that in the remains of the partially preserved layer of the "zolnik layer II" and on the edges of the object, there are types with a potentially younger dating. This remark concerns, among other things, iron pins with heads tapped and rolled up in an ear shape (type II/1), pins with the head in the form of a wave-shaped bent rod (type 4) and specimens of the I/1 variety. At the same time, there are no forms with the chronology falling to the last quarter of the 7 th century BC. At this stage, in the face of significant damage to the object and the presence of objects with a wide range of dating, it is not possible to determine the number of usable phases, and thus the upper limit of the functioning of the complex. It is quite probable, however, that the chronology of the zolnik goes beyond the framework of the Early Scythian period. The lower layer of the zolnik, which has been preserved, should probably date to the first half of the 6th century BC.

The results of the analysis of the pins also allow us to look anew at some aspects related to the functioning of the Scythian culture community in the Chotyniec burgwall. In many respects, it seems to be a model of social structure that differs from the local cultural traditions of the Bronze Age. It should be emphasized that, in light of the findings to date on the gender determinants of the population of Scythian culture groups, pins are considered an attribute of women's attire. Their relatively large abundance at the zolnik, i.e., in a place of a ritual purpose, may suggest the involvement of women in the sphere of ceremonies taking place there. 


\section{Adresy Autorek:}

Dr Joanna Adamik-Proksa

Instytut Archeologii Uniwersytetu Rzeszowskiego

ul. Moniuszki 10; 35-015 Rzeszów

e-mail: j.adamik86@gmail.com

iD https://orcid.org/0000-0002-0661-2046

Mgr Ewelina Ocadryga-Tokarczyk

Instytut Archeologii Uniwersytetu Rzeszowskiego

ul. Moniuszki 10; 35-015 Rzeszów

e-mail: ewelina.ocadryga@gmail.com

iD https://orcid.org/0000-0002-3043-6281 
